\title{
TORT JURISDICTION IN AMERICAN ADMIRALTY
}

\section{Gustavus H. Robinson $\dagger$}

The history and background of our admiralty ${ }^{1}$ show that in the main we have adopted the general maritime law, largely in the manner of our adoption of the common law. Both were part of our English heritage, but both in our hands have taken on such form here as our national needs and circumstances have shaped. Our admiralty adoption finds its basis in Article III, section 2 of the United States Constitution: "The judicial power shall extend . . . to all cases of admiralty and maritime jurisdiction." The "judicial power" referred to was that "of the United States", as the prior section makes obvious by vesting it "in one Supreme Court, and such inferior courts as the Congress may from time to time ordain . . .." This makes clear the judicial authority of the United States in all cases of admiralty and maritime jurisdiction. The legislative authority of the United States in the matter is not so clear. There is no specific grant. But the constitutional language of the judicial grant has been uniformly construed to include legislative authority, ${ }^{2}$ and in I934 Chief Justice Hughes could say that "the grant was regarded as implicitly investing legislative power... . in the United States" 3 over matters maritime.

Thus the United States, as an international personality among the world's sovereigns, has announced to the world that it is prepared to avail itself of a body of law of which the adjectives "admiralty" and "maritime" are descriptive. Where among its own internal organization it would lodge its maritime jurisdiction was a purely domestic matter. But the language by which the Constitution adopts such jurisdiction for the United States is also the language by which it parcels out the jurisdiction internally between the states and the federal government. Thus the detailed definition of the general descriptive words has operated, in our maritime history, not merely to indicate what the maritime law is but also and in the same breath to indicate the respective areas of the federal and state power under the Constitution.

† A. B., 1905, LL. B., 1909, S. J. D., 1916, Harvard University; author of CASES oN PuBLIC UTILITIES (2d ed. r935); The Interacting Areas of Regulatory Authority in Public Utilities (1928) 76 U. of PA. L. REv. 394; The Filed Rate in Public Utility Law (1928) 77 U. of PA. L. REv. 2I3; and other articles in various periodicals; Professor of Law, Cornell Law School.

I. See Robinson, An Introduction to American Admiralty (I935) 2I CoRN. L. Q. 46.

The subject matter of the present article will form the substance of a chapter in a text on admiralty which the author is preparing.

2. Id. at 5 I.

3. The Thomas Barlum, 293 U. S. 2I, 43 (I934). The case sustains the Federal Ship Mortgage Act of I920, and is discussed in the writer's article on admiralty jurisdiction in contract to appear in the April issue of the Tulane Law Review (Vol. Io, No. 3, I936). 
Connotations for the wording of the Constitution have been established largely by decisions of the federal rather than of the state courts. ${ }^{4}$ On the whole their definitions have tended to expand the meaning of "admiralty and maritime". Whether one is to regard the extension of federal power as a mere by-product of the primary operation of establishing, by definition of the few bare words of the Constitution, the content of that body of law which the new nation at its founding had adopted or vice versa, is a speculation of no immediate interest here. The dual aspect of the courts' labors in the admiralty field, however, has no doubt affected the consistency of their decisions. The similar dual aspect of the judicial labors in giving content to "interstate commerce" is a more familiar illustration of the difficult role in our constitutional scheme which the courts assumed to be theirs and which they have staggered under ever since they first took up the burden. Much of what appears to be mere metaphysics or worse, in such matters, for instance as deciding "admiralty jurisdiction" by "localizing" a personal injury, on ship or dock, can be ascribed to the delicacy of the borderline between state and federal domestic authority.

\section{General Principles of Tort Jurisdiction}

In defining the constitutional language the courts have treated admiralty and maritime in two grand divisions: "torts" and "contracts". Neither division is quite accurate if one understands by "tort" a liability arising out of fault and by "contract" a liability formally assumed by offer, acceptance and haggling over terms. For to the tort side the Longshoremen's and Harborworkers' Compensation Act has been ascribed, ${ }^{5}$ while salvage and general average, both arising out of imposed liability, have been assigned to the contract jurisdiction. ${ }^{6}$ Both tort and contract are dealt with, however, in special connection with admiralty and maritime waters and with what might be called admiralty and maritime objects. A word must be given to explaining the new phrases. Roughly, the admiralty waters are nowadays waters which are navigable in fact, whether fresh or salt, tidal or non-tidal, which are open to interstate passage though the commerce need not be interstate nor foreign. This formula describes our own territorial waters. Other waters, whether high seas or foreign territorial, are likewise within the admiralty jurisdiction in the court-competency sense of the word. Questions

4. The original Judiciary Act [I STAT. 76 (I789), 28 U. S. C. A. \$4I (3) (I927)] saved to suitors a "common law remedy when the common law is competent to give it". This may be sought in the state courts. See Robinson, Legal Adjustments of Personal. Injury in the Maritime Industry (1930) 44 HaRv. L. REv. 223, 244.

5. 44 STAT. I424 (I927), 33 U. S. C. A. \$\$ 901-950 (Supp. I935). See Legis. (I928) 28 Cor. L. REv. 88. In Crowell v. Benson, 285 U. S. 22 (I932), the Court pointed out that by its own terms the act was applicable only to "workmen engaged in maritime employment". Also, as later shown herein, only when the men are injured on the water, $i . e$, under the same terms as tort jurisdiction.

6. For these topics and the matter of quasi contract, over which admiralty jurisdiction is in a confused state, see Robinson, loc. cit. supra note 3 . 
concerning the waters which are within the admiralty jurisdiction have been dealt with at some length by the present writer in other articles. The various matters preliminary to the topic of the present paper include not only questions of the waters but also the definition of what is a "vessel" within the maritime jurisdiction. ${ }^{7}$ That definition has been examined on the positive side as to what is included in the word "vessel". In the present paper the effort will be largely toward setting it off from shore structures which though used for maritime purposes are not maritime objects for jurisdictional purposes. Wrongful death in admiralty, its conflict of laws problems and those involving admiralty tort in general on the conflicts side, have also been fully discussed elsewhere. ${ }^{8}$ They are not the subject here. The purpose of the present paper is to deal with the decisions which, on the "tort" side, have built up content for the phrase used in the Constitution. ${ }^{9}$ Torts may be injuries to things or to persons. In order that injury to a thing may be within admiralty jurisdiction the thing injured, in general, must be a vessel, or cargo connected with a vessel, or be some other structure which may be termed a "maritime object". Moreover, in order that injury to a person may be a maritime injury the person must be on a vessel or other maritime object. Finally, both the thing and the person when injured or damaged must be injured on the admiralty waters. On the tort side the foundation statement is that of Story in De Lovio v. Boit, ${ }^{10}$ that the constitutional delegation of cases of "admiralty and maritime jurisdiction" "comprehends all maritime contracts, torts, and injuries. The latter branch is necessarily bounded by locality," and the locality required is that of the waters over which admiralty extends.

\section{Suits by Land Structures for InJury by Vessels}

Assuming the waters to be such as may be called admiralty waters, cases involving injury by vessels to vessels are the most typical of maritime torts. Either vessel may invoke the maritime jurisdiction against the other. But in a collision between a vessel and a structure not within the maritime categories the vessel alone may resort to admiralty. In the development of this topic the typical case is that of a vessel in collision with a "land structure", and the

7. Robinson, loc. cit. supra note I. REv. 406 .

8. Robinson, Wrongful Death in Admiralty and the Conflict of Laws (1936) 36 CoL. L.

9. See generally Brown, Jurisdiction of the Admiralty in Cases of Tort (I909) 9 Cor. L. REv. I; Hough, Admiralty Jurisdiction- of Late Years (I924) 37 HARv. L. REV. 529; Stumberg, Tort Jurisdiction in Admiralty (1926) 4 TEx. L. REv. 306; Farnum, Admiralty Jurisdiction and Amphibious Torts (1933) 43 YALE L. J. 34 ; Note (1927) 75 U. of PA. L. REv. 655 .

xo. Fed. Cas. No. 3776 (C. C. D. Mass. 1815). In Waring v. Clarke, 46 U. S. $44 I$ (I847), the Supreme Court accepted the proposition that locality was the test but devoted itself to the question whether the waters involved were admiralty waters. Philadelphia, Wilmington \& Baltimore R. R. v. Philadelphia \& Havre de Grace Steam Towboat Co., 64 U. S. 209 ( 1859 ) concerned the collision of a ship with a pile left submerged on the Susquehanna River. In a unanimous decision the court briefly held that locality was the test. Panama R. R. v. Napier Shipping Co., 166 U. S. 280 (1897) followed the earlier case. 
cases which have worked out the principles of tort jurisdiction are frequently the same as those which establish the Supreme Court's line of cleavage between the "land structure" class and the maritime structure class.

The Plymouth ${ }^{11}$ is the first case to be examined. By the negligence of those in charge of her a vessel went afire, and from her the fire ran to the wharf. Its owners sued in admiralty, and their libel was dismissed for lack of jurisdiction. The wharf owners argued that the damage was a mere incident to the wrongful acts which took place on the navigable waters; but the Supreme Court said "the entire damage . . . occurred, not on the water, but on the land. The origin of the wrong was on the water, but the substance and consummation of the injury on land".12 "The case is not distinguishable from that of a person standing on a vessel or on any other support in a river and sending a rocket or torpedo into the city by means of which buildings were set on fire." Concluding, the court stated: "the whole, or at least the substantial cause of action arising out of the wrong, must be complete within the locality upon which the jurisdiction depends-on the high seas or navigable waters." The court then localized the injury upon the wharf and held that there was no maritime jurisdiction.

In Ex parte Phenix Ins. Co., ${ }^{13}$ a steamer set fire to river bank property by sparks from her stack. Her owners sought limitation of liability under the Federal Act then permitting limitation to a low "value" which has since been greatly enlarged by recent legislation. ${ }^{14}$ The court said that there was no jurisdiction in admiralty over the loss of the river bank property and concluded that therefore no limitation proceedings could be entertained in favor of the vessel. The first proposition has remained undisturbed but the latter one has ceased to be law by subsequent decision. The curiosity now obtains that while the shore victim may not himself invoke the admiralty law the floating tortfeasor may invoke it against the shore victim's common law suit. $^{15}$

I1. Hough v. Western Transportation Co., I3 Wall. 20 (U. S. I865).

12. Id. at 33 .

13. II8 U. S. 610 (1886).

14. The Act provided that under certain conditions the liability of the owner of a vessel should not exceed the value of his interest in the vessel after the disaster. The history and policy of the statute is set out in Note (1935) 35 Cor. L. REv. 246. At p. 264 the notewriter sets out a bill for modification of the limitation. This passed during the summer of I935; see the amendment of August 29, I935; 48 STAT. 960 (1935), 46 U. S. C. A. \$ I83 (Supp. I935) amending 9 STAT. 635 (185I), 46 U. S. C. A. § I83 (I929). It now provides that the total liability of the owner, etc., "for the entire loss of life or personal injuries caused without the fault or privity of such owner . . . shall be in an amount not less than an amount equal to $\$ 60$ for each ton of the tonnage" or the owner's interest if it be a greater amount. See Am. Mar. Cas. I26I (I935), and Purdy, The Recent Amendments to the Maritime Limitation of Liability Statutes (I935) 5 BrookLYN L. REv. 42.

15. In Richardson v. Harmon, 222 U. S. 96 (19Ir), a vessel which injured a bridge was permitted to limit liability. The Court read the Limited Liability Act of I85I to be intended to permit the ship owner to limit in respect to all claims "whether the liability be strictly maritime or from a tort non-maritime." There is nothing in the r935 Amendment, sitpra note I4, which modifies the decision in this respect. 
In the Plymouth case counsel asserting the jurisdiction argued that, as both the wharf and the vessel were maritime things, the whole matter fell into the admiralty scope. This the court said was a "misapprehension"; wharves figured as land structures, not as aids to navigation. Although the category of land structures which are so far accepted as aids to navigation as to justify extending the admiralty jurisdiction over their injury has since been considerably expanded, wharves have not yet been so classified. They are still "land structures". Nor has counsel's suggestion that there was admiralty jurisdiction for any injury by a ship found favor.

The Plymouth decision was followed in Johnson v. Chicago \& Pac. Elevator Co., ${ }^{16}$ decided in I886. A warehouse owner there sued in a state court for the loss of corn which ran out into the water when the jib boom of a schooner was punched through the warehouse wall. The schooner's owners argued that the proceeding was in rem and so within the exclusive jurisdiction of the admiralty. ${ }^{17}$ That the state court was an improper forum the Supreme Court denied. It said that there was no martime tort: "the substance and consummation of the wrong having taken place on land and not on navigable water, and the cause of action not having been complete on such water." 18

In The Blackheath, ${ }^{19}$ in which jurisdiction was taken of an injury by a vessel to a beacon fixed in the ground but standing in the water, Justice Holmes for the court speaks of the "dicta" in the Plymouth case but also asserts that in the latter the damage was done wholly upon the land. Justice Brown welcomed the Blackheath decision "as practically overruling the former ones" in holding that injury by a ship gave maritime jurisdiction in favor of a land structure. ${ }^{20}$ But Justice Holmes did not purport "to encounter" The Plymouth, and in later cases Justice Brown's view that land injury if done by a ship was within the jurisdiction was expressly rejected. The Blackheath decision, however, furnished the starting point for a new category of amphibious maritime objects, injury to which may be taken cognizance of by our admiralty courts. By The Raithmoor ${ }^{21}$ injuries to such land structures as are in "aid of navigation" are now brought within the admiralty jurisdiction. Thus a new line of catch words has been developed, and the simple statement that maritime jurisdiction does not extend to a land structure cannot be made. Yet though the new formula might logically bring

16. II9 U. S. 388 (I886).

17. For this controversy see Robinson, supra note $\mathrm{I}$, at 56 . By the original Admiralty Jurisdiction Act of I789 [I Stat. 76 (I789), 28 U. S. C. A. \$37I (I928)] the common law remedy was saved to the states, but the particular remedy for the proceeding in rem was confined to the federal admiralty courts.

I8. IIg U. S. at 397 .

19. I95 U. S. 36I (1904).

20. See Note (I929) 42 HARv. L. REv. 563, for a discussion of the topic and of a proposed statute enacting Justice Brown's view.

2I. 24 I U. S. 166 (I9I6). 
into admiralty jurisdiction injury to all types of wharves, piers and jetties, the decisions following The Raithmoor and The Blackheath do not purport to upset the prior holdings on this type of structure. ${ }^{22}$

In 1908 in Cleveland Terminal \& Valley R. Co. v. Cleveland Steamship $C o .{ }^{23}$ a vessel struck a railroad bridge and also a dock or wharf below it. Their owners libelled in rem, and the Supreme Court declared there was no jurisdiction. No argument could bring the railroad bridge into the "aid of navigation" category, but following the Plymouth and the Chicago Elevator cases the court lumped all the structures together: "But the bridge, shore docks, protection piling, piers, etc. pertained to the land . . . none of these structures were aids to navigation in the maritime sense". ${ }^{24}$ The Troy, ${ }^{25}$ which involved injury solely to a railroad bridge over the Mississippi, went the same way without comment; and both were cited in a memorandum decision in The Phoenix Construction Co. v. Steamer Poughkeepsie, ${ }^{26}$ which sustained the dismissal of a libel against a vessel for damages to a pipe on the bottom of the Hudson River. Injury to a drawbridge by a vessel was properly cognizable in a state court in rem because not a maritime tort, the Court held in Martin v. West ${ }^{27}$; and Mr. Justice Van Devanter was there able to cite The Plymouth and The Blackheath in the same list of cases and next to each other. Thus both are to be reckoned with, and even after the Raithmoor decision the older rule that there is no jurisdiction for injury by ships to shore structures, even though the latter are aids to navigation in the wide sense of the term, is still stated as law.

The new phrase has played its part in recent decisions, however. In I925, in The Panoil, ${ }^{28}$ the court said that a dyke, injured by a steamer, must be regarded as land. It had been built by the United States government in aid of navigation. It does not appear to have reached the shore. Extending 700 feet at right angles to the channel it was designed to gather

22. See Farnum, supra note 9, at 39. Mr. Farnum discusses with approval Justice Brown's assertions. He shows that under English admiralty there is jurisdiction if the injury is "by any ship".

23. 208 U. S. 3 I6 (I908). The Court specifically repudiated Justice Brown's view and reasserted that "bridges, shore docks, protection piling, piers, etc. (of the Cleveland Terminal Co.) pertained to the land". The decision in The Troy, 208 U. S. 321 (I908) was to the same effect. In Brown, supra note 9, at I3, the writer discusses prophetically the embarrassments concerning wharves and piles, etc., which are entailed by the American rule. See Judge Hough's comment, supra note 9, at 531, on how deeply Mr. Justice Brown "sympathized" with the discontent of the bar over the rule "which relegates to law redress for injuries done by a floating ship to objects firmly affixed to land, though that land be under water".

24. 208 U. S. at 32I. The Court "distinguished" the Blackheath as involving what was an "aid to navigation". Id. at 320 . Obviously the "aid to navigation" phrase is to be taken in no general sense.

25. 208 U. S. 321 (I908).

26. 2 I2 U. S. 558 (I908). The lower court opinion [I62 Fed. 494 (S. D. N. Y. I908)] shows that the pipe protruded from and was surrounded by water, but its purpose was to make borings in the river bed as part of the construction of a water conduit under the river.

27. 222 U. S. I9I (I9II).

28. 266 U. S. 433 (I925). 
deposits of sediment and thus build up the shore, resulting in improvement of the channel. But the court said, "We think the principle of those cases (Blackheath, Raithmoor) does not go so far." On the other hand, in The City of Ellwood, ${ }^{29}$ the private owners of a cluster of piling sued the United States for injury to the piling by government vessels. In granting jurisdiction, the court said that although they were attached to the land in that they were driven to the bottom of the river, yet they were surrounded by navigable water and intended as aids to navigation. The use was merely for mooring. The case may be taken to determine that mooring piles are within the jurisdiction even though they are privately owned. Yet the point had not been conceded in the lower court. ${ }^{30}$

In so far as United States government property is concerned, recent litigation has taken a different form, and the federal owner has found it worth while to invoke a jurisdiction other than the admiralty. When the steamer Gansfjord struck a jetty wall at the mouth of the Mississippi, the local United States attorney proceeded against her under the River and Harbor Act. ${ }^{31}$ In The Gansfjord ${ }^{32}$ the court stated that the injury being to "a structure which is to be regarded as land was not cognizable in a court of admiralty"; but held nevertheless that the libel in the law side of the court in rem against the vessel for damages was a proper proceeding under the particular statute invoked. ${ }^{33}$

Whatever the difficulties of setting off the maritime structures, it is clear from the foregoing discussion that anything labelled a "land structure" is outside the maritime jurisdiction. If it is injured its owners cannot avail themselves of the admiralty remedies nor invoke them with respect to contracts concerning it. That remedy peculiar to the admiralty, suing in rem and making the offending ship a security for the damage, is closed to them. Damage to piers and other water front property by ships is frequent. If the vessel is under a compulsory pilot, as is usually the case in

29. Doullut \& Williams Co. v. United States, 268 U. S. 33 (I925).

30. See Southern Lighterage \& Wrecking Co. v. United States, 284 Fed. 978 (E. D. La. 192I), aff'd without opinion, 260 U. S. 699 (I922); The Baron Jedburgh, 299 Fed. 960 (W. D. Wash. I924).

3r. 30 STAT. II52, II53 (I899), 33 U. S. C. A. $\$ \$ 408$, 4II-I2 (I928). It imposes a fine for damage by a vessel to any sea wall, wharf or pier built by the United States and imposes liability for the actual damage done enforceable by a libel in rem in admiralty. Although the court considered that the act did not violate the locality rule because it was penal in nature, it would seem that the locality test for admiralty jurisdiction applies equally to crimes as well as torts. See $\mathbf{3 5}$ STAT. II42 (I909), I8 U. S. C. A. \$ 45 I (I927); Atlantic Transport Co. v. Imbrovek, 234 U. S. 52, 60 (I914).

32. I7 F. (2d) 6I3 (E. D. La. I927); $25 \mathrm{~F}$. (2d) 736 (E. D. La. I928). The quotation in the text is from the opinion in $32 \mathrm{~F}$. (2d) 236 (C. C. A. 5th, 1929), cert. denied, $280 \mathrm{U}$. S. 578 (1929).

33. If the structure is land so that no admiralty jurisdiction can attach, a state might protect its wharf or pier property or indeed any private property of similar sort by a similar statute. For if the matter in question is non-maritime, a lien in rem may be created by a state though it must be enforced against the ship in admiralty. Martin v. West, 222 U. S. IgI (IgII); Rounds v. Cloverport Foundry and Machine Co., 237 U. S. 303 (IgI5). 
harbors, there can be no recovery in personam ${ }^{34}$ against the owners, although there would be a basis for a suit in rem against the offending ship if the injury were to a vessel..$^{35}$ But there is no maritime jurisdiction in rem or in personam for the owners of the land structure, and there has been not a little discontent with the present rule. ${ }^{36}$ In I930 a committee of the Maritime Law Association recorded that it favored the extension of admiralty jurisdiction to cover damage caused to land structures by vessels. ${ }^{37}$ The change, if any is made, will have to be by Congressional legislation rather than by judicial legislation. For the Supreme Court has been careful to set caveats upon its recent enlargements of the category of maritime objects.

In 1925 , in Doullut $v$. United States, ${ }^{38}$ in granting jurisdiction for injury to a mooring pile, the Court was careful to say that the piles constituted no part or extension of the shore "as wharves, bridges and piers do".39 Thus it may be said that in the latest view of the Court the structure, in order to be within the admiralty, must not only be an aid to navigation but must not be an extension of the shore, though it may rest on the bottom. ${ }^{40}$

These considerations explain The Poughkeepsie, ${ }^{41}$ where the pipe, though surrounded by waters of the Hudson River and imbedded in its bottom was not, of course, an aid to navigation. Water pipes, gas pipes, and pipe lines laid across or along waterways would not be within the jurisdiction. On the other hand, buoys and channel markers are clearly within

34. Homer Ramsdell Co. v. La Compagnie Générale Transatlantique, I8z U. S. 406 (IgOI).

35. The China, 74 U. S. 53 (I868).

36. Bruncken, secretary of the Milwaukee Harbor Commission states the arguments in Tradition and Common Sense in Admiralty (I929) I4 MARQ. L. REv. I6.

37. Cf. its Document No. I58 dated January 17, 1930; and its further Document No. I72, of May, I93I.

38. 268 U. S. 33 (I925). The constitutionality of an act extending maritime jurisdiction to injury to shore structures by ships would seem to be covered, argumentatively at least, by the reasoning used to sustain the Ship Mortgage Act of I920. The Thomas Barlum, 293 U. S. 2I (I934). The latter case explained away The John Jay, I7 How. 399 (U. S. I854), in which the Supreme Court had denied the very jurisdiction which the new act conferred. The matter is set forth in detail in the author's paper cited supra note 3.

39. In Hough, supra note 9, at 533, the late Judge Hough, who both at the bar and on the bench was an admiralty lawyer of the first rank, remarked: "Truly, as Holmes, J., remarked when he started trouble in The Blackheath, the scope of admiralty jurisdiction is not a matter of 'obvious principle or very accurate history', and it is just as true now as when Brown, J., wrote in his essay [loc. cit. supra note 9], that 'the certainty of the law would have been better conserved, either by following the Plymouth case in The Blackheath, or overruling it in the subsequent cases'." Hough also remarks that the cases repudiating Brown's view "all disposed of without mention of The Blackheath, were a wet blanket to the lower courts".

40. The Senator Rice, 234 Fed. ror (E. D. N. Y. I9I6) involved a vessel's collision with a drilling platform from which work was being conducted in the interest of bettering the channel for navigation. The injury to the platform was held not to be within the admiralty jurisdiction.

4I. I62 Fed. 494 (S. D. N. Y. I908), aff'd without opinion, 212 U. S. 558 (I908). The Phoenix Construction Co. was locating an aqueduct under the Hudson and had made certain borings into the bed of the river. "This boring (collided with) was composed of various lengths of wrought iron pipe surmounted by a platform on the surface." The vessel struck the "platform and pipes". 
the Blackheath doctrine, as no doubt would be range lights and other harbor markers, certainly if they stand in the water. Those range marks which stand on the land, test the whole theory which underlies the Blackheath rule. A wharf or other structure, at least if its feet were in the water, might figure as an aid to navigation rather than merely a wharf if it had a range marker on its outshore end. Injury, even if by sparks from a vessel to the respective steeples of the First and Second Baptist churches of a river town, which steeples together might serve "Mark Twain" as range finders, would fall into the admiralty jurisdiction if the rule is pressed hard enough. That the line is not easy to draw is illustrated by the status of piles or dolphins driven into the bed of the waters. In the Doullut case ${ }^{42}$ they were "used by vessels to tie up to so as to avoid anchor dragging" and passed muster as "aids to navigation", so that on their injury by a vessel jurisdiction was found, as we have seen. But in two other cases logging companies maintained dolphins, piling and boom equipment which passing ships broke up, and in both jurisdiction was denied. ${ }^{43}$ Although in one of them ${ }^{44}$ the libellant pleaded that the log storage was for the purpose of export by oceangoing ships to Japan, the court nevertheless said the allegation was insufficient to show jurisdiction. The locus of the injury to them was "on land", the court insisted.

With respect to submarine cables the "aid to navigation" phrase seems to have been overworked in the lower courts, where alone as yet the question has appeared. In several earlier cases the cable owner's suits had been both dismissed ${ }^{45}$ and retained ${ }^{46}$ without discussion of the jurisdiction point. But in $19 \mathrm{r} 5$, in Postal Telegraph Cable Co. v. P. Sanford Ross, ${ }^{47}$ in which a dredge boat broke apart and dragged out of place a telegraph cable in the Arthur Kill, it was sharply debated. The ship's counsel cited the Plymouth, Blackheath, etc., cases, but the court decided that the accident did occur within the physical limits of admiralty jurisdiction ${ }^{48}$ since a cable is more akin to matters connected with the ocean than land. This case and the one which followed it ${ }^{49}$ made no point of the character of the cable in question. United States v. North German Lloyd Co. ${ }^{50}$ involved simply a "govern-

42. Doullut \& Williams Co. v. United States, 268 U. S. 33 (I925).

43. Hakushika Maru [1930] A. M. C. 918 (D. Ore. I930); Shiraha Maru [I93r] A. M. C. 470 (W. D. Wash. I93I).

44. Shiraha Maru [I93I] A. M. C. 470 (W. D. Wash. I93I).

45. Stevens v. Western Union Telegraph Co., Fed. Cas. No. I3,37r (E. D. N. Y. I876) (propeller and cable entangled).

46. The City of Richmond, 43 Fed. 85 (S. D. N. Y. I880); The William H. Bailey, I00 Fed. II5 (D. Conn. 1900).

47. 22I Fed. I05 (E. D. N. Y. I9I5).

48. The court remarked that if the same cable had been carried across the stream in the air or on a bridge there would be no jurisdiction. This is reminiscent of the airplane cases as discussed in Robinson, supra note I, at 77 ; see also infra note I05.

49. The Toledo, 242 Fed. I68 (D. N. J. I9I7). It involved an injury to the same company's cable at a point in the Kill von Kull near the Jersey shore. The court followed the Sanford Ross Case, supra note 47.

50. 239 Fed. 587 (S. D. N. Y. IgI7). 
ment cable" across the Narrows in New York Harbor, and the court held the jurisdiction settled by the Sanford Ross case, which the court considered unshaken by the intervening Raithmoor decision. In deference to the latter it added that the "cable itself was connected with the subject of navigation", but how connected is not stated. On the other hand, in The Majestic ${ }^{51}$ jurisdiction was sustained, apparently with respect to the same cable, which was described as "used solely for military, fire control and harbor defense purposes". Saying that counsel for the Majestic sought to distinguish as "doubtful" the three cases last stated, the court nevertheless followed them. It considered the cables in question aids to navigation and commerce. Thus an injury to cables as cables is not a land injury insofar as the important district courts centering around New York City ${ }^{52}$ are concerned and these courts appear to be astute in connecting the cables with the aid to navigation category.

Courts elsewhere have been less willing to see the mere locality of the injury as the test for maritime tort. In Postal Telegraph Co. v. Tugboat Elsie ${ }^{53}$ a California district court said there was jurisdiction; but the circuit court of appeals in the Kanagana Maru case ${ }^{54}$ not only denied the application of the New York cases to the power cables which had been injured but cast doubts on the telegraph cable cases as well. Certiorari was denied by the Supreme Court.55 In The Mont Agel, ${ }^{56}$ in dismissing a libel filed by the Western Union Telegraph Company for injury to its wires the court declined to follow the New York cases and adhered to the Oskaloosa, ${ }^{57}$ a piling case which itself is presumably upset by the Doullut case, ${ }^{58}$ though the decision that there was no jurisdiction in the Oskaloosa case was in fact affirmed without opinion by an equally divided Supreme Court. In the field of cable cases The D. E. Callender ${ }^{59}$ revealed a new twist of fact. A power company's cable having been previously broken, some 400 feet of it was floated by buoys or barrels for repair, and it was with the floating cable that the Callender tangled its propeller. The court decided this to be a tort which occurred upon the water and held for the jurisdiction. It concluded 1932).

51. United States v. Oceanic Steam Navig. Co., Ltd. [1932] A. M. C. I079 (S. D. N. Y.

52. Postal Tel. Cable Co. v. Central Hudson S. B. Co. (The Benjamin B. Odell), [1926] A. M. C. 49 I (E. D. N. Y. 1926), was heard on its merits but went off on a finding that the injury the cable had suffered was not brought home to the "Odell".

53. The Elsie, 288 Fed. 575 (N. D. Cal. rg23).

54. Kanagana Maru, Nippon Y. K. v. Great Western Power Co., I7 F. (2d) 239 (C. C. A. 9th, I927), 7 B. U. L. REv. 204, 36 YALE L. J. IOI5.

55. 274 U. S. 745 (1927).

56. [I924] A. M. C. 40 I.

57. Southern Lighterage Co. v. United States, 284 Fed. 978 (E. D. La. I92I), aff'd without opintion, 260 U. S. 699 (1922). An Emergency Fleet Corp. vessel struck a cluster of piling at the foot of a New Orleans street, used "for the mooring of vessels or the keeping of them in deep water when unloading cargo".

58. 252 Fed. 544 (C. C. A. 8th, 1918).

59. 3 I F. (2d) 486 (W. D. Wis. I 928 ). 
that under the circumstances "this cable in fact was being navigated"-a fact which "distinguished" the Kanagana Maru case. ${ }^{60}$ The Supreme Court refused certiorari in the Kanagana Maru; but the general subject of cable injury needs authoritative settlement, one way or the other, by that tribunal.

\section{Suits by Vessels Against Bridges, Etc.}

Whatever the jurisdictional intricacies presented when the bridge or wharf or cable owner seeks to sue the vessel there is no question that if a floating vessel strikes a bridge or wharf the locus of the tort, if any to the vessel, is on the water so far as the vessel's suit is concerned. There is no doubt about the vessel's admiralty suit against the wire owner for injury by the wires to the vessel. This is neatly brought out in Burke v. Southern Bell Tel. and Tel. Co. ${ }^{61}$ where a steamer stack struck the telephone company's wires, which had been strung across a river and allowed to sag. Exceptions to the jurisdiction were overruled. For here the court was on familiar ground. ${ }^{62}$ As Holmes, J., remarked in The Blackheath: ". . . if the beacon had been in fault and had hurt the ship a libel could have been maintained against the private owner, although not in rem" ${ }^{63}$ and in admiralty. This was settled doctrine. Long before, in The Philadelphia, Wilmington \& Baltimore R. R. v. Philadelphia \& Havre de Grace Steam Torvboat Co ${ }^{64}$ when a steamer struck certain piles left in the river after a proposed railway bridge was abandoned, her suit in admiralty was upheld over the contention that the leaving of the piles was a common law nuisance for which action on the case was the remedy. ${ }^{65}$ In The Rock Island Bridge ${ }^{66}$ the vessel which struck the bridge had libelled the bridge in rem, and the Supreme Court sustained the objection taken to jurisdiction in rem. In denying seizure of the bridge because the proceedings in rem are based on the maritime lien the court stated that a maritime lien exists only with respect to movables engaged in navigation or movables which are the subjects of commerce upon the high seas or navigable waters. Jurisdiction in personam was conceded ${ }^{67}$ and has always since been conceded. In Atlee v. Packet Company ${ }^{68}$

60. Nippon Y. K. K. v. Great Western Power Co., I7 F. (2d) 239 (C. C. A. 9th, I927), cert. denied, 274 U. S. 745 (1927).

6I. 42 F. (2d) 724 (S. D. Ala. 1930), (I93I) 44 HARv. L. REv. 460.

62. In Stevens v. Western Union Telegraph Co., Fed. Cas. No. I3,37 I (E. D. N. Y. 1876) the court sustained jurisdiction for damage to a ship's propeller by a submerged telegraph cable.

63. I95 U. S. at 365 (I904). The beacon was a government one and the word "private" has reference to the traditional non-suability of the government, a subject discussed in a valuable note in (I930) 39 YALE L. J. I I89.

64. 23 How. 209 (U.S. I859).

65. The court said: "It is a rule of maritime law, from the earliest times, "that if a ship run afoul of an anchor left without a buoy, the person who placed it there shall respond in damages' (see Emerigon, Vol. I, page 4I7, Consulat de la Mer, chap. 243; and Cleirac, 70)." 23 How. at 216.

66. 6 Wall. 213 (U. S. 1867 ).

67. Id. at 216 . Speaking of the maritime lien the Court continued: "It may arise with reference to vessels, steamers and rafts, and upon goods and merchandise carried by them. 
the owners of a barge filed a libel in admiralty against the owner of a pier. Mr. Justice Miller stated the jurisdiction of the district court sitting in admiralty was not validly questioned. By $I 896$ the question had ceased to be arguable. ${ }^{69}$

In the Atlee case the court not only entertained jurisdiction in behalf of the barge but it applied the admiralty damage rules in its favor ${ }^{70}$ and gave it half damages despite its own contributing fault. This is scarcely "sporting" from the bridge owner's angle. He must, under the doctrines already set forth, sue at common law. He cannot sue in admiralty. Even where the bridge and the ship are both at fault, the bridge still must sue at common law and the traditional common law effect of its contributory negligence will prevent its recovering anything. This of course invites the ship to get into the forum in which its negligence will cost it least. It may not only sue in admiralty in the first place and on its own motion; it may drag the bridge owner out of a common law forum by a petition for limitation of liability, as will be shown later. ${ }^{71}$ Furthermore, if the ship owner should take the initiative of suing in admiralty the bridge owner may not except to the libel. The ship is properly in admiralty. But the bridge may file a cross libel. The court then is faced with a maritime and a non-maritime claim with the latter before it as an incident to the former. But it takes no leaf out of the book of the courts of equity. It does not dispose of both. ${ }^{72}$ In such a case the cross libel of the bridge owner has no better standing than would the same cause of action if brought by him on an original libel. In The Kearney ${ }^{73}$ that vessel struck a drawbridge whose owners filed a cross libel to the Kearney's libel.

But it cannot arise upon anything which is fixed and immovable, like a wharf, a bridge, or real estate of any kind. Though bridges and wharves may aid commerce by facilitating intercourse on land, or the discharge of cargoes, they are not in any sense the subjects of maritime lien." In so far as the beacons of the Blackheath and Raithmoor cases are considered government property, they are not subject to seizure in proceedings in rem. Whether the cables formerly discussed are so far taken out of the "land structure" class as not only to be in the jurisdiction as libellants but also for being proceeded against in rem by an injured ship is not discussed in the cases.

68. 2I Wall. 389 (U. S. 1874 )

69. Panama R. R. v. Napier Shipping Co., I66 U. S. 280, 284 (I8g6).

70. Atlee v. Packet Co., 2I Wall. 389, 395 (U. S. I874). The Court said: "By the rule of the admiralty court, where there has been such contributory negligence, or in other words, when both have been in fault, the entire damages resulting from the collision must be equally divided among the parties." The subject is discussed in Mole and Wilson, A Study of Connparative Negligence (I932) I7 CoRN. L. Q. 333. See also Sprague, Divided Damages (I928) 6 N. Y. U. L. Q. Rev. I5; Huger, The Proportional Danage Rule in Collisions at Sea (IO28) I3 CORN. L. Q. 53I.

7r. See note 72 infra, and p. 730 infra.

72. United States v. Norfolk Bridge Co., 29 F. (2d) II5, I3I (E. D. Va. I928). The problem of mixed claims has been affected by the decision of Taft, C. J., in Hartford Accident Co. v. Southern Pac. Co., 273 U. S. 207 (I927), in reading the powers of an admiralty court similar to those of an equity court in this particular at least when dealing with the Limitation of Liability Act, when a limitation is applied for by a defendant. That act consolidates various plaintiff claims into one suit in admiralty and an injunction is issued against prosecution of the plaintiff's claims elsewhere. This feature inspired the opinion of the Chief Justice. The whole topic is dealt with in detail in Robinson, loc. cit. supra note 3.

73. I4 F. (2d) 949 (C. C. A. 3d, I926), (1927) 25 MicH. L. Rev. 789. 
The vessel was found to be wholly at fault $;^{74}$ consequently the libel was dismissed, whereupon the cross libel was likewise dismissed. "Cross libels may be filed upon any counter claim arising out of the same . . . cause of action or matter auxiliary to it for which the original libel was filed." 75 But the court held that the scope of this rule "is confined to maritime subjects. Its evident purpose was to expedite by a single suit the disposition of all maritime claims arising out of the same" cause and that after the dismissal of the libel there was nothing before the court except a cross libel on a nonmaritime claim. ${ }^{76}$ If both parties are in fault it is not altogether clear what would be done for the bridge on its cross libel. If its damage so greatly exceeded that to the vessel that, on the division, money was due the bridge, the principle of The Kearney would seem to call for dismissing the cross libel, thus depriving the bridge of any recovery at all, since its same contributory negligence which caused the division of damages would defeat it altogether at common law. ${ }^{77}$ In Northern Pacific Ry. Co. v. Duluth S. S. $C o .{ }^{78}$ the steamer filed a libel against the owner of a bridge. The steamer was found contributorily negligent, and the court said that the bridge owner "is entitled to recoup its damages . . . and as its damages are greater than those of the steamship company, to a decree of dismissal of the suit on its merits." 79 It is wholly silent on decreeing that the bridge recover anything positively. In United States $v$. Norfolk-Berkley Bridge Corp. ${ }^{80}$ both ship and bridge were found to be in fault, with slight damage to the vessel and very large injury to the bridge. The case got into the admiralty court by activities of the ship, which filed a petition for limitation of liability; and the form of the proceedings were therefore such that in the particular instance the court achieved a result which lessens the hardship on shore struc-

74. The basis of liability in admiralty is discussed by the present writer in Legal Adjustments of Personal Injury in the Maritime Industry (1930) 44 HARv. L. REv. 223, 234. Liability, in general, has been based in the admiralty as at common law, on fault, though a partial job insurance is to be found in "maintenance and cure" for seamen as set forth later in an article, The Seaman in Admiralty, to appear in the April issue of the BostoN UNIVERSITY LAW REVIEW (Vol. 16, I936). The Harbor Workers' Act, based on non-fault compensation, has been referred to supra note 4 .

75. This is Rule 50 of the Admiralty Rules of the Supreme Court of I920. 254 U. S. 702,28 U. S. C. A. \$ 408 (I926).

76. United Transport \& Lighterage Co. v. New York \& Baltimore Transport Co., I85 Fed. 386 (C. C. A. 2d, IgII) seems to be the only prior case and it held the same way. $C f$. The Electron, 48 Fed. 689 (S. D. N. Y. I $89 \mathrm{I}$ ).

77. In the Callender case the court held both parties to be in fault but did not face the problem of the Kearney case since he also held the vessel's injury to the floating cable, the subject of the cross-libel, to be maritime. The use of the common law rule in hearing an admiralty claim was discussed and objected to by the present writer in (r930) 44 HARv. L. REv. 223, 244. State courts have used it in such cases but no objection could be made to their use of it in a litigation for bridge damage since the latter is non-maritime.

78. 252 Fed. 544 (C. C. A. 8th, I9I8).

79. The bridge was damaged $\$ 2200$ worth, the ship $\$ 1800$. Both were negligent. But the court says nothing about decreeing that the owner of the bridge recover $\$ 200$ from the owner of the ship. See Ebert v. The Reuben Dowd, 3 Fed. 520, 530, 53I (E. D. Wis. I880) ; The North Star, I06 U. S. I7, 27 (1882); Bowker v. United States, I86 U. S. I35, I40 (I902).

80. 29 F. (2d) ins (E. D. Va. I928). 
tures. Following the suggestion of Chief Justice Taft in the Hartford Ins. Co. case, the court said:

"It is beyond dispute that if the Bridge Corporation had been permitted to proceed with its action at law, no recovery would have been had if it had transpired that neglect on its part had contributed to the injury. It would seem to follow logically that when the common law action is enjoined, ${ }^{81}$ and the Bridge Corporation files its claim in admiralty in limitation proceedings, it cannot recover unless it shows that it is possessed of a right of action at common law. The authorities cited ${ }^{82}$ tend to show that the nature of the action is not changed by its transfer to the admiralty court. It follows that the Bridge Corporation can have no recovery in this case unless its rights are in some way affected by the Áct of Congress which regulates limited liability proceedings." 83

It held however that the rights were affected. In Hartford Accident Co. $v$. Southern Pacific, ${ }^{84}$ Taft, C. J., for the Court, had said that the Limitation Statute was aimed at facilitating settlements of the controversies involving losses that it concerns; and the ease present in the adjustment of suits in equity is intended to be given to the proceedings. It is intended that the administration of equity should be present in an admiralty court. ${ }^{85}$ From this language the Virginia District Court concluded that it could not be understood that the bridge should recover nothing anywhere. It consequently decreed after division a recovery of the excess in the bridge's favor. In In re Pennsylvania $R$. R. $C o{ }^{80}$ a Pennsylvania Railroad tug had the misfortune to set adrift over twenty barges which later were both damaged and did damage; and some wrecked a boardwalk in New Jersey. As owner of the tug the Railroad Company began the reported proceeding by filing a petition for limitation of liability. As both the boardwalk owner and the tug were found to be in fault, the case presented again the problem whether the boardwalk owner should take anything in the admiralty suit. The court held that it should. Its reason ${ }^{87}$ was that the admiralty rule will govern

8I. The effect of the petition for limitation was to enjoin the bridge from proceeding at common law. See ante note 72 .

82. Western Fuel Co. v. Garcia, 257 U. S. 233 (192I) ; Engel v. Davenport, 27I U. S. 33 (1926); Chelentis v. Luckenbach S. S. Co., 247 U. S. 372 (I918) were cited.

83. $29 \mathrm{~F}$. (2d) at 130 .

84. 273 U. S. 207 ( 1927 ).

85. This is not the usual idea concerning the admiralty court. It is not a court of equity ; and Taft, C. J., himself went on to say that it was not, and to emphasize that he was speaking only of the limitation proceeding.

86. 48 F. (2d) 559 (C. C. A. 2d, I93I).

87. L. Hand, J., said that the doctrine concerning contributory negligence ordinarily is that it is of the substance of the right but held that as the admiralty cases went "We can see no escape, therefore from concluding that as between a common law court and a court of admiralty the question is treated as one of procedure though the general law is otherwise." Id. at 566. He added that on the only decision in point which he had found, Judge Soper had arrived at the same result by a very different reasoning, citing the Berkley Bridge case. In (I930) 44 HARV. L. REv. 223, 246, the present writer objecting to the use of the common law contributory negligence rule, relied on Port of $\mathrm{N}$. Y. Stevedoring Co. v. Castagna, 280 Fed. 6I8, 624 (C. C. A. 2d, 1922), cert. denied, 258 U. S. 63I (I922), in which 'Judge Hand's court 
if the forum is an admiralty forum. This would seem to do away with the whole difficulty in any case where a non-maritime cause of action is involved and seems to prove too much if taken conversely, since it would follow that a maritime cause of action in a common law court would also be given the common law rule. Where the vessel filed its libel and the bridge cross libeled, this forum rule would assist the bridge, it is true, but on the other hand it leaves the bridge owner limited to a common law court as plaintiff and equally helpless as before to invoke the admiralty rule unless the vessel cites him in a limitation proceeding. ${ }^{88}$ The Supreme Court's reading of the matter is not altogether clear so far as non-maritime claims are concerned and the whole treatment of contributory negligence as affected by the choice or accident of forum needs clarification. ${ }^{80}$

So far we have been discussing the cases where, by the vessel's initiative, the litigation was in the admiralty at the outset. If the owner of the shore structure invokes the common law forum, as he must, it is apparent from the recently discussed cases that even if he is free of contributory negligence he cannot keep the case in the common law courts against the vessel owner's move for limitation of liability. In I9II, in Richardson $v$. Harmon, ${ }^{90}$ the receiver of a railroad sued in an Ohio state court for a $\$ 35,000$ damage to the railroad's bridge, obviously a non-maritime tort. In granting the vessel owners' petition for limitation of liability to the value of the vessel ${ }^{91}$ the admiralty court moved the case out of the state court and restricted the bridge owners' recovery to the barge's value, $\$ 4000$. In affirming, the Supreme Court so read the Limitation Act ${ }^{22}$ as to cover liability for all claims whether

followed the orthodox conflict of laws rule as set forth in Restatenrent, Confict of LAws (I934) § 385, "Whether contributory negligence of the plaintiff precludes recovery in whole or in part . . . is determined by the law of the place of wrong." That is, if the injury is lea loci maritime the damages should be divided as they were in Fitzpatrick v. International Ry., 252 N. Y. 127,169 N. E. II2 (I929) where the injury was in Ontario and the New York court applied the Ontario law of divided damages, a thing it refused to do in a case of maritime tort in Meleeney v. Standard Ship Bldg. Co., 237 N. Y. 250, I42 N. E 602 (Igz3). In the Brinton case Judge Hand disposes of this Castagna decision by saying that it was overruled in Johnson v. United States Corp., 24 F. (2d) 963 (C. C. A. 2d, I928).

The United States Supreme Court refused to grant certiorari in the Brinton Case, 284 U. S. 640 (I93I).

88. Judge Hand declined to extend the idea of the Hartford Accident Co. v. Southern Pac. Co., 273 U. S. 207 (I927), so far as to administer state workmen's compensation claims in a limitation proceeding. See The Linseed King, 52 F. (2d) I29 (C. C. A. 2d, I93I). The Supreme Court considered that no state compensation claims were involved, and in Spencer Kellogg Co. v. Hicks, 285 U. S. 502 (1932), in reversing the court of appeals' grant of limitation in The Linseed King, held that the state compensation act did not apply to the torts and that the deaths of the men in the case were maritime.

89. It also stated in the case of the Linseed King that the court felt that an admiralty court having taken jurisdiction and brought all claimants into concourse should give complete relief. Thus in an unsuccessful petition for liability limitation the court held that if all claims which were in the very case were maritime they could be adjudicated. The case throws little light on the adjudication of non-maritime claims.

90. 222 U. S. 96 (I9II). At substantially the same time in Martin v. West, 222 U. S. IgI (IgII), the Court sustained a state act giving the bridge owner a lien on the ship on the score that the injury was non-maritime.

91. See the amendment and discussion in note 14, supra.

92. See sitpra note 15 . 
it be strictly maritime liability or liability from a non-maritime tort. Thus the shore structure cannot prevent the application in the ship's favor of the divided damages rule, nor of the limitation of liability statute: but under the Hartford-Southern Pacific Co. rule the shore structure, if cited into a limitation of liability proceeding, is protected against the full results of the common law rule of contributory negligence. All claims are settled on the spot, including that of the shore structure, and the latter, if itself negligent, has the benefit of having them decided on the admiralty basis of divided damages.

\section{Temporarily Maritime and Non-maritime ObJects}

So far we have perhaps tacitly assumed that a vessel is always a vessel and $a$ wharf always a shore structure. But a vessel may be afloat in a capacity other than a vessel and if it be used as a floating wharf, say, it may cease to be tied up and go to sea on its own. A shore structure which breaks loose from shore and floats does not thereby become a vessel. The cases recognize that the intention with which the fabric is being used when it suffers an alleged maritime injury, or on which a personal injury asserted to be maritime is sustained, may affect the maritime jurisdiction.

Furthermore, many of the decisions are interpretations of "vessel" or a kindred word as used in a statute; and the word is given a connotation merely in the light of the special purposes of the enactment ${ }^{93}$ or indeed for the purpose of the very suit aside from any statutory definition. The fabric, for instance, may not be the subject of salvage, perhaps, when it might have a maritime aspect for another purpose. There may be a variable between the treatment of the same structure for contract jurisdiction and for tort jurisdiction. The status of an incomplete structure which when completed will unquestionably be a vessel is an illustration. For contract purposes it is no vessel. No maritime flavor attaches to a contract for work done on the fabric even after it is launched into the water. The Supreme Court held in The Francis McDonald ${ }^{94}$ that no maritime lien arose in favor of a builder who completed a ship after her launching by a prior builder who failed to finish her. Yet in Tucker $v$. Alexandroff ${ }^{95}$ for a non-admiralty purpose the same Court had said that the launching made the structure a "ship". For admiralty jurisdiction in tort, moreover, the launching made it so far a vessel that the injury of a workman on board a newly launched ship was specifically stated to be within the admiralty jurisdiction in Grant Porter Ship Co.v. Rohde. ${ }^{96}$ Just when a newly built ship becomes a "vessel" is not

93. See (I927) 36 YALE L. J. 4I5, where this is brought out with illustrations.

94. Thames Towboat Co. v. Schr. Francis McDonald, 254 U. S. 242 (1920), (I92I) 21 CoL. L. Rep. 28r. The case and others are discussed in Robinson, loc. cit. supra note 3.

95. I83 U. S. 424 (1902). A vessel when launched was a ship within the meaning of a treaty by which the United States engaged to apprehend deserters from a ship. The decision is now confined to its precise facts.

96. 257 U. S. 469 (1922). The case went off in favor of applying a state compensation act but only on the ground that it was a "local" matter and the workman's right to damages 
stated by the Supreme Court in The Francis McDonald. ${ }^{97}$ It merely held the contract in question not to be maritime. But the facts show that the launched and incomplete hull was towed from the yard of the original builder in New London, Connecticut, to that of the libellant in New Jersey. Had it had adventures, or had it done injury, during the tow, or had the towing company raised a question of maritime lien for its services, the jurisdiction problem would have been raised in an embarrassing form. As Judge Hough commented, she was sufficiently a ship for towing and undoubtedly would have incurred a maritime lien for a collision en route, but was not regarded enough of a vessel to be liable for her own finishing. ${ }^{98}$

The intent for use test furnishes also some clue to the present status of a structure which concededly has been a vessel and may even again be such but is now being put to some special use. Old vessels are often cheaply bought for use as hotels, for dance halls, for show boats and recently for what the moving picture people call a "prop". ${ }^{99}$ The Hendrick Hudson 100 laid down the working principles as early as I869. An old steamboat, stripped of its boilers, engines and paddle wheels and in service as a saloon and hotel, grounded while being towed from one location to another and was assisted by the libellant, who sought a salvage award. In denying it, Judge Blatchford ${ }^{101}$ said, "Although this hulk or structure had once been a vessel, in the full sense of the term .. . and although its form and shape under water continued to be those of a vessel . . . this hulk was not, in any proper sense, engaged in commerce or navigation." In Evansville \& Bowiling Green Packet Co. v. Chero Cola Bottling Co. ${ }^{102}$ the precise question was

in admiralty was abrogated by the state act. See Hoof v. Pacific American Fisheries, 279 Fed. 367 (C. C. A. 9th, 1922), also holding that injury on an incomplete but floating ship was within the admiralty jurisdiction.

In Taylor v. Lawson, 60 F. (2d) I65 (E. D. S. C. I932) it was held that a man injured on an uncompleted vessel while building was under the Longshoremen's Act. (r933) 46 HARv. L. REv. JII, is critical, but the case rests itself squarely upon the Rohde decision. See further on the case infra note 215 .

97. The Court worded its question "Was appellant's contract to furnish materials, work, and labor for her completion, made after the schooner was launched but while not sufficiently advanced to discharge the functions for which intended werthin the admiralty and maritime jurisdiction? The District Court thought not and so do we". 254 U. S. at 242.

98. In Hough, Admiralty Jurisdiction-Of Late Years (1924) 37 HARv. L. REv. 529, 534. Cf. Blatchford, J., in The Hendrick Hudson, Fed. Cas. No. 6,355 (S. D. N. Y. I869) in which the court denied a salvage recovery for aid to a hulk, floating and towable but used as a hotel saying: "The service did not fairly and legitimately concern any right or duty which appertained to commerce or navigation or to a structure engaged in commerce or navigation. Whether the structure in question would or would not be liable in rem, in the admiralty, for a tort or injury committed on navigable waters depends on different considerations. . . ."

99. See "Old Ironsides"-The Llewellyn J. Morse, 25 F. (2d) 973 (D. C. Cal. 1928). The old vessel was used in making the picture called "Old Ironsides". Men were hurt, and the question arose in respect to a limitation of liability available to a "vessel". Here status was inferentially not that of a vessel for limitation but limitation was denied on another ground.

I00. Fed. Cas. No. 6,355 (S. D. N. Y. I869).

roI. Afterward Mr. Justice Blatchford.

102. 27 I U. S. I9 (I926), (I927) 36 Y ALE I. J. 4I5. In this case, the boat which was over forty years old had been towed from Arkansas to Indiana to Kentucky to Indiana again. It was 243 feet long, 48 wide, and 6 deep; of wood with a side sheathing of concrete. At 
whether the wharf boat was a "vessel" within the Limitation of Liability Act. This was the precise question also in Old Ironsides. ${ }^{103}$ In each case the court said it was not a "vessel" for the purpose of limitation. But in the case of Old Ironsides the men injured on board in the course of the production of the picture sued in admiralty for their injuries and won. The wharf boat case does not indicate where the owners of the freight sued. Their claim for damage to the freight because of the "wharf boat's" sinking is discussed below. ${ }^{104}$ The point to be emphasized here is that determining the character of the structure as a maritime object or not a maritime object for one purpose is not a settlement of the question for every possible purpose. And it may be possible even that a thing which is no vessel on the defendant's side for limitation is a vessel on the side of a plaintiff who seeks an admiralty forum for personal injury.

The "intermittent" maritime object doctrine has been illustrated by the treatment of the airplane. In I92I, in Reinhardt v. Newport Flying Service, ${ }^{105}$ Cardozo, J., made a distinction between hydroplanes afloat and in the air. He considered that a man who was hurt while aiding a hydroplane at anchor in navigable waters of the United States was hurt within the admiralty jurisdiction. Professor Cook points out that "Cardozo, J., apparently assumes that there is a single definition of 'vessel' for all purposes of admiralty law, and thus by a process of what fairly may be called 'mechanical jurisprudence' reaches his conclusion". ${ }^{106}$ Cook also remarks that, under the decision, "We thus have the somewhat curious result that the crew are entitled to compensation under the state compensation law for injuries received while the plane is 'in the air' but not for those which occur while the plane is 'on the water'." 107

the time of the occurences litigated, it was secured to the shore with four or five cables and merely moved up and down the levee with the stages of the river. It had no motive power and it had connection with the city's water and electric and telephone systems. In Hayford v. Doussony, 32 F. (2d) 605 (C. C. A. 5th, 1929) the "Pirate Ship" was secured to the dock, not like an ordinary ship, but with cables and clamps, the cables having eight or ten turns around clusters of piling. Built ashore was a permanent gangway with a house over it extending to the wharf. Electric wires and waterpipes connected the structure with the shore. The structure was used only as a dance platform. The court considered that the Evansville case governed. In The Showboat, 47 F. (2d) 286 (1930), the Massachusetts District Court felt that, as the mooring was less permanent and the wiring easily detachable, the pleasure boat was a "vessel".

103. 25 F. (2d) 973 (D. Cal. 1928), cited note 99, supra.

104. Infra, p. 747.

105. 232 N. Y. II5, I33 N. E. 37 I (I92I), Io CALIF. L. REv. 232, (I922) 22 CoL. L. Rev. 272, (I922) 3 I YALE L. J. 437.

106. Substance and Procedure in the Conflict of Lazes (I933) 42 YALE L. J. 333, at 338. 107. A recent English decision, Watson v. R. C. A. Victor Co., 50 L. T. R. 77 (1934), dealt with the case of a seaplane whose S. O. S. message was picked up by Watson's trawler while the latter was off Greenland. Watson searched the area stated by the S. O. S. to be the seaplane's position and finally located the seaplane "on a rocky isle surrounded by the ice-pack", where it had foundered. The passengers and crew were able to scramble ashore with equipment worth 3000 pounds, which Watson saved. "Can a seaplane be regarded as in the nature of a ship or vessel so as to bring it and its cargo within the law relating to salvage at sea?" asked the court. It answered: No. This English case was discussed by Arnold W. Knauth in a very valuable paper on Aviation and Salvage: the Application of Salvage Prim ciples to Aircraft (1936) 36 CoL. L. REv. 224. He considered the result "unexpected". 


\section{Jurisdiction in Personal Injury Cases}

Admiralty jurisdiction with respect to injuries to persons rather than to things also goes back to the Plymouth rule ${ }^{108}$ that "every species of tort, however occurring, and whether on board a vessel or not, if upon the high seas or navigable waters, is of admiralty cognizance," and particularly that "the wrong and injury complained of must have been committed wholly upon the high seas or navigable waters, or at least the substance and consummation of the same must have taken place upon these waters." There has been much hair-splitting in the detailed application of these formulas. In injury to things, the things are required to be upon the waters engaged in some maritime purpose; "in aid of navigation" is the latest catch-phrase developed out of the Blackheath doctrine already discussed. Presumably injury to a person who is on one of these structures when injured will be put within the admiralty jurisdiction if the doctrine is logically carried out. The pure locality test, however, cannot be said to be all-sufficient in respect to admiralty jurisdiction over injury to persons on board even maritime things on admiralty waters. In dealing with personal injury on the waters there has been a persistent question over whether the jurisdiction is concerned with the character of the man's reason for being on the waters. Is it sufficient that he was aboard a maritime object upon the waters, or must his reason for his position have a maritime character? This question can scarcely be given a clear answer.

In 1873 one Blessing boarded The Natchez, Captain Leathers, at a wharf in New Orleans. While on board, he was hurt, and in Leathers $v$. Blessing, ${ }^{109}$ his case reached the Supreme Court on "The only question . . . whether the suit was one in the admiralty jurisdiction. . . A Attention is directed to the facts that the Circuit Court did not find that the libellant was an officer, seaman, passenger or freighter or that he had any connection with the vessel, or any business upon her or about her, except that when he went on board of her he was expecting a consignment of cottonseed by her. . . . It is urged that the case is one of an injury received by a person not connected with her navigation. . . ."110 The Court, however, addressed itself only to the question of the propriety of his boarding the vessel. Finding him an invitee under a custom to permit enquirers for cargo to board vessels, the Court held that jurisdiction depended on locality and affirmed a recovery in Blessing's favor. Whether one may rate this a case where maritime purpose was not needed, or was needed and found, is not obvious.

The pure locality test, however, was attacked in 1903 in Campbell $v$. Hackfeld $\&$ Co., ${ }^{111}$ which denied that injury on maritime waters to a steve-

I08. Hough v. Western Transportation Co., 70 U. S. 20 (I865), cited note II, supra.

109. 105 U. S. 626 ( $188 \mathrm{r}$ ).

II0. Id. at 628 .

III. I25 Fed. 696 (C. C. A. 9th, I903), criticized in (I903) I6 HARv. L. Rev. 21o. See also Note (IgT2) 25 HARv. L. Rev. 38 r. 
dore was within the jurisdiction on the ground that locality alone was not sufficient in absence of maritime character. The precise result of the case is definitely upset by the later Imbrovek decision ${ }^{112}$ in the Supreme Court that a stevedore's is "a maritime employment"; but the Court's statement that in tort as well as in contract "to bring a case within the jurisdiction of a court of admiralty, maritime relations of some sort must exist, for the all-sufficient reason that admiralty does not concern itself with non-maritime affairs" and that locality alone is no test, has hardly been clarified.

Atlantic Transport Co. v. Imbrovek ${ }^{113}$ concerned the injury of a stevedore hurt while working on board a ship in Baltimore harbor. The locality requirement was fully met. But the vessel owners urged that, in every case heretofore adjudicated, "the tort apart from the mere place of its occurrence had maritime character." To this the Court responded: "Even if it be assumed that the requirement as to locality in tort cases while indispensable, is not necessarily exclusive, in the present case the wrong which was the subject of the suit was, we think, of a maritime nature and hence the District Court from any point of view had jurisdiction. . . We entertain no doubt that the service in loading and stowing a ship's cargo is of this character." 114 Thus there was jurisdiction; but the opinion does not settle whether there was jurisdiction because locality and maritime character coincided, or whether there was jurisdiction merely because of the locality. One Circuit Court of Appeals judge has since cautiously stated the tort rule that occurrence on navigable waters was "prima facie the test", ${ }^{115}$ but felt it necessary also to look at the "quality of the act". In White v. John W. Cowper Co. ${ }^{116}$ the court in a New York district said "the barge was moored in navigable waters and the character of the work (unloading her) was such as to confer a right to redress in admiralty". In I922, the Second Circuit Court of Appeals said, however, that Mr. Justice Story had declared that jurisdiction was exclusively dependent on locality and "this rule has frequently been declared by the Supreme Court", citing the Imbrovek case without further comment. ${ }^{117}$ It used similar language in Port of New York Stevedoring Co. v. Castagna."18 Other courts have said "the locus of the accident is upon navigable waters, and this is the test of admiralty jurisdic-

II2. 234 U. S. 52 (I9I4).

Ir3. Ibid.

II4. Id. at $6 \mathrm{I}$.

II5. Learned Hand in Sidney Blumenthal v. United States, 30 F. (2d) 247, 249 (C. C. A. 2d, I929): "The jurisdiction of the admiralty over such a tort (in the case) admits of no question; it took place upon navigable waters which is prima facie the test. Atlantic Transport Co. v. Imbrovek, 234 U. S. 52. It is true that in that case the question was left open whether there might not be torts committed on the water of which the admiralty would not take cognizance. Assuming as much, and that therefore the quality of the act may at times be determinative this was a maritime transaction [carriage of goods by sea]. . . . If any tort be maritime, certainly this was one."

II6. 260 Fed. 350 (1919).

II7. Netherlands S. N. Co. v. Gallagher, 282 Fed. I7I (I922).

II8. 280 Fed. 618,623 (1922), cert. denied, 258 U. S. 631 (1922). 
tion in cases of tort".119 "Every tort, however occurring, if upon the high seas or navigable waters is of admiralty cognizance." 120 It is, however, true that in all of these cases the work had some maritime flavor. They show the attitude of the inferior federal courts, and they mirror the lack of clarity in the Supreme Court's views both in and since the Imbrovek case.

In The Raithmoor, ${ }^{121} \mathrm{Mr}$. Justice Hughes, who also had written the opinion in the Imbrovek case, said of the beacon for injury to which jurisdiction was granted: "It was . . . at a place where the jurisdiction of admiralty in cases of tort normally attached-at least in all cases where the wrong was of maritime character." Although citing both the Plymouth and the Imbrovek cases, the former of property damage, the latter of personal injury, he does not explain his own phrase last quoted. No doubt he was influenced by the fact that he was dealing with a property case. In Chelentis v. Luckenbach S. S. Co., ${ }^{122}$ involving injury by a wave to a seaman while his ship was at sea, McReynolds, J., is found saying: "The work . . . is maritime in its nature: his employment was a maritime contract; the injuries received were likewise maritime and . . . clearly within the admiralty jurisdiction", ${ }^{123}$ citing the Imbrovek case. In Grant Smith-Porter Ship Co. v. Rohde ${ }^{124}$ the lower court asked instruction ${ }^{125}$ concerning the admiralty jurisdiction in case of a carpenter injured while at work on board a new vessel incomplete but already launched in navigable waters. The precise question was on the application of the state Workmen's Compensation Act and the case belongs to that subject.126 But McReynolds, J., says, "The general doctrine that . . . admiralty jurisdiction depends . . . in tort matters upon the locality, has been so frequently asserted by this court that it must now be treated as settled." ${ }^{127}$ He cited The Plymouth, ${ }^{128}$ Martin $v$. West, ${ }^{129}$ and added, "see Atlantic Transport Co. v. Imbrovek; and Hughes on Admiralty 2 d ed. p. I95". By all the rules of jurisdiction in contract, since Rohde was working on an unfinished ship, ${ }^{130}$ his employment had no maritime flavor contractually, and if his injury was a maritime tort as the Court said, it was a triumph for the assertion that locality alone is the tort

IIg. Buren v. Southern Pac. Co., 50 F. (2d) 407, 408 (C. C. A. 9th, I93I).

120. Young v. Clyde S. S. Co., 294 Fed. 549, 550 (S. D. Fla. 1923) (a laborer employed on a ship was killed on board).

I2I. $24 \mathrm{I}$ U. S. I66, I76 (I916), cited note $2 \mathrm{I}$, supra.

122. 247 U. S. 372 (1918), (1919) 33 HARv. L. Rev. 300.

123. Id. at 382 .

124. 257 U. S. 469 (I922).

125. Under Judicial Code $\$ 239,43$ STAT. 938 (I925), 28 U. S. C. A. $\$ 346$ (Ig28).

126. The Court at pp. $477-478$ held that admiralty jurisdiction did extend to a "tort committed on a vessel in process of construction when lying on navigable waters" but said that the state act applied since it did not prejudice the general maritime law. It was within the "local matters" exception to the uniformity of admiralty law so sharply insisted on in the case of Southern Pac. Co. v. Jensen, 244 U. S. 205 (I9I7).

I27. Id. at 476.

128. Hough v. Western Transportation Co., 70 U. S. 20 (I865), cited note II, stupra.

I29. 222 U. S. I9I (IgIr), cited note 27 , supra.

I30. The ship was not yet a vessel. See Robinson, supra note 3. 
test, ${ }^{131}$ though it went off in favor of the state jurisdiction under a doctrine that the tort was "local" in character.

In London Guarantee \& Accident Co. v. Industrial Accident Comm. ${ }^{132}$ the state commission had applied the State Compensation Act in a case where a boy employee of a fishing company lost his life in seeking to rescue a boat which broke loose while moored about a mile off shore; considering it a matter of "local" concern within the Rohde case. This interpretation was denied, and the commission's award was upset. Said Taft, C. J., for the Court: "Here it is without dispute that the deceased was a sailor, that his employment and relation to the owner of the vessel were maritime" 133 and he stressed the non-maritime character of the Rohde case: "neither Rohde's general employment nor his activities at the time had any direct relation to navigation." 134 These remarks, it is true, may have to do with explaining why the local rule did apply in the Rohde case and did not in the London Guarantee case, but they illustrate the persistence of the discussion in the cases of the character of the work as a factor in tort jurisdiction in admiralty on the personal injury side. In I924 Judge Hough could still say: "What Brown wrote in $1908{ }^{135}$ is still true: 'Whether the word "tort" as thus used (i. e., the locality rule) includes every act within the common law definition of the word, or is confined to such as are in some way connected with the equipment, navigation or discipline of the ship has not been judicially decided." "136 Certainly persons who have had no

I3I. In Hoof v. Pacific Am. Fisheries, 279 Fed. 367 (C. C. A. 9th, Ig22), cert. denied, 263 U. S. 7I2 (I923), not only was the ship not completed but the injured man was a watchman who fell while making his round. That his work was non-maritime the court conceded so far as contract claims might lie but put the case on his service for the ship on a vessel in maritime waters. Where, however, a completed ship is on land in a dry dock for repairs, the recent cases hold that an injury on board is maritime. In The Warfield, rzo Fed. 847 (E. D. N. Y. rg03), where a man fell through a hatch on the ship, the court dismissed his libel solely for want of jurisdiction. But in The Anglo-Patagonian, 235 Fed. 92 (C. C. A. 4th, 19I6), cert. denied, 242 U. S. 636 (I9I6), the court held the other way, as did The Iowan [1923] A. M. C. 303 (D. Ore. r923). See also The Steamship Jefferson, 2r5 U. S. I30 (I909).

132. 279 U. S. 109 (1929).

133. Id. at I20.

134. Id. at I23.

135. Brown, loc. cit. supra note 9.

136. Hough, cited stipra note 9, at 532. Judge Hough continues: “Justice Brown's essay assumed, as axiomatic, acceptance of the formula that jurisdiction in tort depends on locality. But like all thoroughbred admiralty men, he sympathized with Mr. Erastus Benedict's celebrated doubt whether a libel published and circulated exclusively on ship board would support a libel in admiralty." Judge Hough adds that, notwithstanding the Blackheath decision, "the question of the sufficiency of the locality test would not down". Of the Supreme Court's handling of the Imbrovek case, Hough says: "If the locality rule is a sufficient statement of doctrine a plainer case for its application could not exist. Justice Hughes, for a unanimous court, restated that doctrine in its boldest form; but instead of there leaving the matter, perfectly clear whether satisfactory or not, he justified the result by pointing out that 'service in loading and stowing a ship's cargo is of a maritime nature'. Legal principles cannot permanently be stated in this way. The locality rule is either sufficient or lacking in completeness, and unless it would destroy the rule as formulated, not even the Supreme Court can always avoid answer by bolstering up with immaterial matter a case which demands application, enlargement, or disaffirmance of the rule." Ibid. 
contract relationship or workman relationship with maritime objects but who have been injured at what might be called maritime places have recovered in admiralty on no other basis than mere locality.

Recently however Congressional legislation has so far narrowed the field of debate that if the injured person is a workman the character of his work does become a factor. It must be maritime in nature. In I927 Congress passed a Compensation Act for Longshoremen.137 "The general scheme . . . was to provide compensation to employees engaged in maritime employment . . . ." 138 Chief Justice Hughes said of it: "As the Act relates solely to injuries occurring upon the navigable waters of the United States it deals with the maritime law applicable to matters that fall within the admiralty and maritime jurisdiction." 139 By its own wording its "coverage" is stated to be "if the disability or death results from an injury occurring upon the navigable waters of the United States (including any dry dock)." ${ }^{140}$ This provision concerning the dry dock is in line with the Anglo-Patagonian decision, ${ }^{141}$ and it seems to make maritime character of the work sufficient for admiralty jurisdiction over an injury on land. But the statute continues: "and if recovery . . . through workmen's compensation proceedings may not validly be provided by state law." This provision, on the other hand, looks toward pure locality as the test. But to counteract it the section also provides that injury means "injury arising out of . . . employment", while "employer" means a person any of whose employees are engaged in "maritime employment". ${ }^{142}$

The locality test, therefore, is not enough to bring a case under the Harbor Workers' Act. Here the maritime character of the employment is vital. Congress has made a statute designed to cover the job hazards of maritime workers while laboring on the water, but not including those job

The whole topic is discussed in Note (1926) 24 MrCH. L. REv. 405, which rejects Mr. Benedict's suggestion so far as the authorities are concerned: "The great weight of authority is otherwise and recent decisions manifest no tendency to deviate from the established doctrine." Mr. Benedict also had remarked: "It may however be doubted whether the civil jurisdiction in such cases of torts does not depend upon the relation of the parties to a ship or vessel embracing only those tortious violations of maritime duty which occur in vessels to which admiralty jurisdiction, in cases of contracts applies. If one of several landsmen bathing in the sea should assault or imprison or rob another it has not been held here that the admiralty would have jurisdiction of the action for the tort." BENEDICT, ADMIRALTY (5th ed. I925) $\$ 308$.

I37. 44 STAT. I424 (1927), 33 U. S. C. A. \$\$ goi-950 (Supp. r935), cited note 5, supra.

138. Nogueira v. New York, New Haven \& Hartford R. R., 28I U. S. I28, I3I (I930), 5 TuLANe L. Rev. I20.

I39. Crowell v. Benson, 285 U. S. 22, 39 (1932).

I40. 44 STAT. I426 (I927), 33 U. S. C. A. \$903 (a) (Supp. 1935).

I4I. 235 Fed. 92 (C. C. A. 4th, 1916), where the ship's anchor slipped letting the anchor down on a staging on which men were working. They were huried to the bottom of the dock. The court declared there was admiralty jurisdiction finding the Imbrovek case "conclusive since no valid distinction can be made . . . between a workman who is hurt loading a vessel and one who is hurt in repairing a vessel". This was to make maritime character override locality.

I42. 44 StAT. I426 (I927), 33 U. S. C. A. §903 (a) (Supp. I935). 
hazards involved in occupation on wharves or ships. But whether the requirement that maritime character in the work coincide with locality of the injury is merely a limit on what Congress did do or a limit on what it might do is not so clear. ${ }^{143}$ Could it have covered work hazards on all jobs done on the water; could it have covered the hazards of maritime work done on land, and in each case remain within the constitutional limits of the admiralty and maritime jurisdiction? In Crowell v. Benson, ${ }^{144}$ Hughes, C. J., said: "In amending and revising the maritime law Congress cannot reach beyond the constitutional limits which are inherent in the admiralty and maritime jurisdiction. Unless the injuries to which the [Longshoremen's] Act relates occur upon the navigable waters of the United States, they fall outside that jurisdiction. . . . Where navigability is not in dispute the locality of the injury, that is whether it has occurred upon the navigable waters of the United States determines the existence of the Congressional power to create the liability prescribed by the statute." This again supports the pure locality test. It argues that Congress could not give longshoremen an afloat and ashore coverage.

A recent decision on the Longshoremen's Act makes clear that the place of injury and the character of the man's work are equal factors in the coverage. In Minnie v. Port Huron Terminal Co., ${ }^{145}$ "Petitioner, a longshoreman, was injured at Port Huron while unloading a vessel lying in navigable water. He was about his work on the deck of the vessel when he was struck by a swinging hoist, lifting cargo from the hatch, and was precipitated upon the wharf". The state compensation board gave him an award under the local state act which the supreme court of the state vacated. ${ }^{146}$ Chief Justice Hughes for the Court agreed that the state act did not apply. ${ }^{147}$ But he put the denial on the point that the man was injured on the navigable waters: "We have held that the case of an employee injured upon navigable waters while engaged in a maritime service is governed by the maritime law. Southern Pacific Co. v. Jensen, 244 U. S. 205; Grant Smith-Porter Ship Co. v. Rohde, 257 U. S. 469. It is otherwise if the injury takes place on land. State Industrial Commission v. Nordenholt Corp., 259 U. S. 263, 272, 273; Nogueira v. New York, N. H. \& H. R. Co., $28 \mathrm{I}$ U. S. 128, I33. In the instant case, the injury was due to the blow which petitioner received from the swinging crane. It was that blow received on the vessel in navigable water which gave rise to the cause of action,

I43. 44 STAT. 1424 (I927), 33 U. S. C. A. \$§ 90I-950 (Supp. I935).

I44. 285 U. S. 22,55 (1932), cited note 139 , supra. The injury was on navigable waters but the question of the case was whether or not the man was an "employee". This important case will be more fully discussed in a separate article on the Harbor Workers' Act.

I45. 295 U. S. 647 (I935), (I936) 3 U. OF CHI. L. REv. 320.

I46. Minnie v. Port Huron Terminal Co., 269 Mich. 295, 257 N. W. 831 (1934).

I47. 295 U. S. 647,648 (1935). 
and the maritime character of that cause of action is not altered by the fact that the petitioner was thrown from the vessel to the land". ${ }^{148}$

Thus the Federal Compensation Act takes care of a maritime worker whose injury occurs on the navigable waters. But what of the worker whose job is non-maritime in character, and who is injured, while on the job, on the navigable waters? If he is injured by a third party his action against that third party is maritime, of course. But if he is injured by a negligence of his employer and seeks compensation or, though injured by act of a third person, nevertheless seeks compensation from his employer, is the State Compensation Act applicable to these cases? Or does the fact that the place of injury is on navigable waters make the claim so far maritime that the state act is ousted here as it is in the cases where the employment itself is maritime?

Two recent cases are to be considered in these connections. They are The Linseed King, ${ }^{148 a}$ decided in the Supreme Court of the United States, and the recent Heaney v. P. J. Carlin Construction Co. ${ }^{148 b}$ decided by the New York Court of Appeals. Either might conceivably have been decided on the theory that the men were not yet so far at work as to be within the scope of the Compensation Act, ${ }^{148 \mathrm{c}}$ but neither was so decided, and assuming that the State Compensation Act is otherwise applicable they present the present inquiry in an acute form.

In each case men who lived on Manhattan Island in New York City worked at a point across a waterway. In the federal case the Spencer Kellogg factory on the New Jersey shore employed them in the manufacture of linseed oil; the Carlin Company's men were bricklayers working on a construction job. on Rikers Island across the East River. In each case men going to work on these jobs suffered death or injury in a disaster which befell the boat on which they were being ferried. But at this point the fact situations diverge. In the Linseed King case the boat was owned and operated by the employer himself; in the Heaney case one Forsythe operated it. He collected fares from the men and he carried other people besides the Carlin workmen. But the Carlin Company guaranteed him a $\$ 60$ per diem income in case he did not take in that much from the individuals carried.

The men in the Linseed King case sued their employer as for a maritime tort. The employer contended that the Limitation Act applied and most of the Supreme Court's opinion deals with the Limitation Act. But the Kellogg

I48. On the same day in Kenward v. The Admiral Peoples, 295 U. S. 649, 65I (1935), the Court reiterated: "The jurisdiction in cases of tort depends upon the locality of the injury." But here the injured person was a passenger disembarking when hurt. See comment (1936) IO TULANE L. REv. 300.

I 48 a. 285 U. S. 502 (1932), 32 COL. L. REv. I06T.

I 48 b. 269 N. Y. 93, I99 N. E. I6 (1935), (I936) 49 HARv. L. REv. 826.

I48c. In such circumstances the New Jersey Compensation Law is applied by the courts of that state, which hold that the relation of employer and employee exists during such transportation. Depue v. Salmon Co., 92 N. J. L. 550, I06 Atl. 379 (I919) ; Alberta Contracting Corp. v. Santomassimo, 107 N. J. L. 7, I50 Atl. 830 (1930). 
Company also argued that the State of New Jersey Compensation Act applied and operated to bar the tort suits. To both contentions the Supreme Court said "No". It denied limitation because the launch was negligently operated with the privity of the owner, saying:

"Kellogg \& Sons undertook the interstate carriage of passengers by water on a launch operated by its servants. This was a maritime matter. The ferriage was for the facilitation of the company's business and for its convenience as well as that of the employees. The injury to the passengers resulted from negligence of the company's agents in the navigation of the launch. It was a maritime tort. The rights and obligations of the parties depended on and arose out of the maritime law. A proceeding to impose liability for such a tort is a cause in admiralty within the meaning of article $3, \S 2$ of the Constitution, triable in the United States courts sitting in admiralty." . . "The Workmen's Compensation Law of New Jersey . . ., the purpose of which was to supersede the common law redress in tort cases and statutory rights consequent upon death by wrongful act, and to substitute a commuted compensation for injury or death of an employee, irrespective of fault, is not applicable to the injuries and deaths under consideration."

"Kellogg and Sons sustained towards employees injured or killed the dual relationship of a carrier by water and a general employer at its Edgewater plant. Under the federal statutes the company, acting in the first capacity, was entitled to a limitation of liability unless the claimants could prove negligence with the owner's privity or knowledge. They assumed the burden of proving such negligence. They sustained it and are entitled to recover according to the rules of the maritime law, including, of course, any applicable death statute."

Notwithstanding the Supreme Court's decision in the Linseed King case the New York Court decided that the State Compensation Act could be applied in favor of the Carlin employees. Speaking for a four-three majority, Hubbs, J., conceded that claims against Forsythe, the boat owner, were based on maritime tort. But as to the claims against the employer he chose to regard their bases as contractual rather than delictual. For this view there is much to be said which the writer has set down elsewhere. ${ }^{148 d}$ Having once taken it, Judge Hubbs was ready to consider its effect on his problem. $\mathrm{He}$ answered that as there was no tort, no admiralty or maritime jurisdiction was involved at all unless it was by reason of the character of the contract of employment:

I48d. The theory that Workmen's Compensation is in the nature of an insurance of job hazards and coextensive with the area of the job has so far replaced the tort or lex loci delicti theory that New York and other states have allowed recovery under their local acts for injury in New Jersey or other states. See Post v. Burger, 216 N. Y. 544, III N. E. 351 (I915) and Cameron v. Ellis, 252 N. Y. 394 , I69 N. E. 622 (I930). A recent article by D. C. Dunlap, (I935) 23 CALIF. L. REv. 38I, collects the literature and the cases. A further article now in preparation will deal generally with the Federal Compensation Act and its relation to the state compensation statutes. 
"If the question of tort be not involved then we are confronted with the question as to whether the contract of employment is maritime in its nature. The contract of employment was for the services of the claimant in the erection of a building. It was not a contract to do work upon a vessel in navigable waters nor even to do work remotely connected with any undertaking having to do with navigation or commerce. The presence of the claimant upon the boat was a mere incident of the contract of employment, it having been found as a fact that he was on the boat as an employee of the contractor against whom the award has been made.

"Even though the part of the contract of employment which brought about his presence on the boat be deemed to make the contract of employment maritime in its nature, the subject remains local in character and the applicability of the state compensation law quite possibly might be upheld in a federal court under the exception to the general rule as to the applicability of maritime law which permits the application of a state statute where so doing will not 'work material prejudice to the characteristic features of the general maritime law, nor interfere with the proper harmony and uniformity of that law in its international and interstate relations.' State Industrial Commission of State of New York v. Nordenholt Corp., 259 U. S. 263, 274."

The Linseed King case was put aside by the majority on its facts :

"In that case the employer who was the owner of the boat, undertook the interstate carriage of passengers by water on a launch operated by its servants, sustained a dual relationship to its employees of a carrier by water and a general employer, and was guilty of a maritime tort. None of these things are present in the instant case. Here, since the employer was not a carrier of passengers by water, it was not guilty of a maritime tort and the proceeding is not one to 'impose liability for such a tort' as the proceeding in the Kellogg Case was held to be."

The dissenters felt that the Linseed King case governed them. They pointed out that:

"The fact that the employer in that case was the charterer or owner of the boat became important and was emphasized by reason of an application made by it to limit liability to the value of the boat as permitted under federal statute. It had nothing to do with shifting or changing the principle that passengers being transported at sea or on navigable waters by a steamer are subject to admiralty jurisdiction."

The Supreme Court has been asked to grant certiorari in Heaney v. Carlin Co., but no decision is likely prior to the going to press of this number.

The Supreme Court's decision on the Carlin case will be eagerly awaited by those interested in the general subject. The litigation shows how difficult a task falls to the court in such cases as these two we have discussed. The result in the Linseed King case seemed right enough on its facts though the present writer has always felt that the gambling tort verdicts in lump sums 
might well be circumscribed in favor of the surer compensation payments. But even a writer with a slant for admiralty jurisdiction in all possible cases cannot but feel sympathetic to the majority's solution of the Carlin case. If a Manhattan trucking concern sends out three drivers, $A, B$ and $C$ with loads for points in New Jersey, and $X, Y$ and $Z$ with loads for points on Long Island, by the majority decision the men are covered by the New York Compensation Act throughout their jobs, in New Jersey, on Long Island and on the way. Whether the men cross the waterways by bridge or ferry or tunnel, their injury during any of these crossings is compensable. If one of them chooses, or all are sent by their employers, to travel by ferry, the Supreme Court is asked to say whether the state compensation coverage is to be in abeyance while they are on the boat. If one starts his fleet of trucks from San Francisco bound for Oakland after the bay bridges are in use and the ferries not yet withdrawn, the same question is raised. On the other hand, does the New York court mean to apply the New York Compensation Act to the journey of every subway straphanger who goes downtown to work? Even if the application of the act is confined only to his journey by water the case seems to go far. Perhaps the New York Court will apply the act only where the carrier as in the Carlin case was subsidized by the employer. In further support of the pure locality test one cannot leave the topic without recalling that persons who have no contract or workman relationship with maritime objects of any kind have frequently recovered in admiralty. ${ }^{149}$

\section{INJURy ON LAND OF A MARITIME WORKER}

However much or little the maritime character of the man's contact with the place is involved when he is injured while on the water, it plays no part in the question of admiralty jurisdiction if he is injured on land. Notwithstanding that the man's contract or service is maritime, if in fact he is injured on the dock it is the locality and not the contract which counts; and in such cases the admiralty jurisdiction in tort is denied. In Netherlands Steam Nav. Co. v. Gallagher, ${ }^{150}$ a stevedore unloading a ship but working on a dock was hurt when the cargo he was handling rolled on him. Following the Imbrovek case ${ }^{15 x}$ the court said: "While the plaintiff's contract was plainly a maritime contract, if he was employed to render a stevedoring service, and one consequently within the admiralty jurisdiction if suit had been brought upon it", yet "the injury done to the plaintiff on the dock was not within the jurisdiction of the admiralty . . . and we do not think

I49. In N. Y. \& Long Branch S. B. Co. v. Johnson, r95 Fed. 740 (C. C. A. 3d, r912) the husband of an injured woman passenger brought suit for the injury to him through the injury to the wife. The court at p. 74I said: "The tort [to Mrs. Johnson] then being wholly maritime, why does not such tort constitute a maritime cause of action to everyone who was injured thereby?" The court held that it did, and Johnson recovered \$II47.

I50. 282 Fed. 17I (C. C. A. 2 d, 1922).

I5I. 234 U. S. 52 (I9I4). 
that that fact affects it." 152 The court concluded that the question whether the tort is maritime or non-maritime does not depend on whether the person who brings the action was, when he was injured, working under a maritime contract. In the various cases, later examined, which seek to determine the precise place of the injury, the assumption which is common to all of them is that the locality alone governs. If the locality is found to be on land, there is no jurisdiction in the various cases where a man working in maritime employment is injured on a wharf. The character of his work is not made a point of. In Industrial Comm. v. Nordenholt, ${ }^{153}$ where a longshoreman was hurt on a wharf while tiering up cargo, the New York Appellate Division ${ }^{154}$ denied the application of state law because it considered that the man's maritime contract threw the case into the admiralty jurisdiction. This, the Supreme Court declared, was a misunderstanding of the famous Jensen case. ${ }^{155}$ The injury, it said, was not maritime, because the man "was injured upon the dock, an extension of the land . . .." "The liability . . . on account of injuries received on ship board by an employee under a maritime contract is matter within the admiralty jurisdiction; but not so when the accident occurs on land." 156 A seaman, whose job is the most maritime of jobs, may not invoke the Seaman's Act for injury on the dock when sent ashore with a mooring line. ${ }^{157}$

\section{Where Is the Tort "Consummated"?}

\section{(a) In Property Damage Cases}

"The wrong and injury complained of must have been committed wholly upon the high seas or navigable waters." This much of the Plymouth formula we have examined. The balance-"or at least the substance and consummation of the same must have taken place upon these waters"-is now to be inquired into. Where is an injury consummated? The task of saying that "here" or "there" was the place of the injury is no simple one. In general terms it has been stated as "the place where the force for which the actor is claimed to be responsible first takes harmful effect upon a person or thing" and the "place of wrong" to be the "place where the plaintiff's alleged right to be free from the act or event . . . is alleged to be violated." ${ }^{158}$ The possible tests are: (I) the locality of the damage; (2) the

I52. 282 Fed. I7I, I77 (C. C. A. 2d, I922). The court examined various Supreme Court cases. Cf. The Canadian Farmer, 290 Fed. 60I (S. D. Cal. I923).

I53. 259 U. S. 263 (1922).

I54. I95 App. Div. 913 (3d Dep't I92I), aff'd, 232 N. Y. 507, I34 N. E. 549 (Ig2I), Cardozo, J., dissenting. The Appellate Division relied upon Keator v. Rock Plaster Mfg. Co., 224 N."Y. 540,120 N. E. 56 (I918), and Anderson v. Johnson Lighterage Co., 224 N. Y. 539, 120 N. E. 55 (I918).

I55. 244 U. S. 205 (I9I7).

I56. 259 U. S. 263,273 (I922).

157. The Montezuma, I9 F. (2d) 355 (C. C. A. 2d, I927). He may, however, have his "maintenance and cure" since he was injured in the service of the ship.

I58. Restatemenr, Conflict of Laws (Tent. Draft, I928) $\$$ 4I I, 4 I8. See the writer's article, supra note 4 , at 229 . In the I934 Restatement of the Conflict of Laws, the sec- 
locality of the origin of the active party's movement; (3) the place where the wrongful force comes in contact with the person or thing injured. Since damage is part of the essence of the tort idea, the second of these may be discarded as between this test and that stated by the others; the illustrations supplied by the decisions are the best clues to what is meant by the admiralty formula. As put by Judge Gilbert, ${ }^{159}$ the Supreme Court's Imbrovek "opinion cites and leaves undisturbed a long line of decisions made both before and since the decision in The Plymouth that where the tort is committed not on the vessel, but on the shore or on a dock, or where it is committed partly on land and partly on water, the question whether admiralty has jurisdiction over it is determined by the place of the damage and not by the place of the origin of the tort."

The mere fact, therefore, that the wrongful act originated upon a ship is insufficient to establish the jurisdiction. In The Plymouth itself the negligence from which the fire arose occurred upon the vessel, whence it carried to the wharf. "The negligence of itself furnished no cause of action: it is dammum absque injuria", said the Court. ${ }^{100}$ It likened the case to that of a person standing on the vessel and shooting rockets which set it on fire, such facts as were substantially presented in Ex parte Phenix Ins. Co., ${ }^{161}$ where the passing ship emitted sparks which set fire to a saw mill on shore and where admiralty jurisdiction was denied. In Johnson v. Chicago \& Pacific Elevator Co., ${ }^{162}$ where the jibboom of a vessel, negligently managed on navigable waters, broke open a storehouse on shore, the actual litigation was not over the injury to the building but concerned the loss of grain which spilled from it into the water. In denying jurisdiction the Supreme Court inferentially denied it for losses by reason of property falling into the water after a vessel had wrecked a land structure. That is to say, it localized the tort at the point where the defendant's force came into contact with the thing injured, notwithstanding that even the principal damage occurred by the resulting precipitation of something into the water. It specifically so held

tions cited have been been restated with the same general ideas. See \$\$ 404-4II. The comment under the then $\$ 404$ embodied the words quoted in the text. The final draft of the Restatement, in $\$ 377$ et seq., deals with the place of wrong. In BEALE, CoNFLICT OF LAws (I935) $\$ 377(2)$, it is said that "the place of wrong is the place where the person or thing harmed is situated at the time of wrong", citing Otey v. Midland R. R., I0 $8 \mathrm{Kan} .755$, I97 Pac. 203 (Ig2r), where an engine located in Kansas emitted sparks which blew over into Oklahoma and ignited Otey's barn. The act was held to be done in Oklahoma and the law of that state applied. The subject of the place of wrong in admiralty was developed by the writer in an article, loc. cit. supra note 8.

I59. In Swayne and Hoyt v. Borsch, 226 Fed. 58I, 588 (C. C. A. 9th, I9I5), he cited many cases and concluded that "The difference between Atlantic Transport Co. v. Imbrovek and the present case is the difference between land and sea. Imbrovek was injured while working on the ship. Borsch, the plaintiff, however, was injured while working on the dock." Borsch like Imbrovek was a stevedore.

I60. I3 Wall. 20, 36 (U. S. 1865).

I6I. II8 U. S. 6I0 (I886), cited note I3, supra. The result is strictly in accord with Mr. Beale's case cited supra note I58.

I62. II9 U. S. 388 (1886), cited note 16 , supra. 
in Martin $v$. West, ${ }^{163}$ where the passing vessel struck and so weakened a bridge pier that a few hours later the bridge fell into the water. The Court said: " . . . the question must be resolved according to the locality and character of the injured thing-the bridge and its spans and supporting piers -at the time of the collision. It was then that the causal influence of the negligent management of the vessel took effect injuriously and gave rise to a cause of action and what followed is important only as bearing upon the extent of the injury and resulting liability". ${ }^{164}$

Prior to the Supreme Court's Chicago Elevator case, in The City of Lincoln, ${ }^{165}$ which arose out of the overloading of a wharf, a district court had said: "the injury to the libellant's steel blooms was effected wholly in the water into which they were thrown through the breaking down of the [overloaded] wharf." The whole "substance and consummation of the injury" were, therefore, on the water. It was the water that did the damage. That was the place of the damage and consequently the place of the tort for the purpose of admiralty jurisdiction. ${ }^{168}$ Later, however, where a steamer ran into a pier so as to carry away portions of it and hurl property and materials therefrom into the water, the court, in The Haxby, ${ }^{167}$ took the view that the whole injury, to the wharf and even to the contents precipitated into the water, was land damage and not within the admiralty. It asked, "Where, then, was the injury done in contemplation of law, upon the land (the pier being land) or upon the navigable waters of the river? . . . I think it must be held that the injury was done upon the pier. It was there that the wrongful violence was inflicted, and what happened afterwards namely the sinking of the blocks and tools was an unavoidable consequence due to gravity. . . . The case is ruled by Johnson v. Elevator Co." 168 Consequently it denied jurisdiction.

In 1925, in Fireman's Fund Ins. Co. v. City of Monterey, ${ }^{169}$ a district court still felt free to choose between the City of Lincoln and Haxby cases, and it elected to follow the City of Lincoln despite the intervening Johnson case. The city of Monterey owned and operated a wharf which collapsed while loaded with canned sardines, and the latter fell into the water. The sardine losers successfully urged that no damage occurred until the boxes

163. 222 U. S. IgI (IgII), cited note 27, supra. See also Hermann v. Port Blakely Mill Co., 69 Fed. 646 (N. D. Cal. I895).

I64. Id . at 197 .

I65. 25 Fed. 835 (S. D. N. Y. I885).

166. Id. at 837. The court added: "Had the goods been, for instance, crockery or glassware . . . broken ... through the breaking down of the wharf ... without being thrown into the water the injury would have been consummated upon the land and no jurisdiction in admiralty would have attached. Rock Island Bridge Co., 6 Wall. 213; The Mary Stewart, Io Fed. Rep. I37; The Accome, 20 Fed. Rep. 642."

167. 95 Fed. I70 (E. D. Pa. 1899).

I68. Id. at I7I.

169. 6 F. (2d) 893 (N. D. Cal. 1925), (I926) 24 MiCE. L. REv. 405. 
reached the water. The court discounted the Chicago Elevator case by saying that it was "influenced by the fact that the building also was damaged and the loss of the corn and the injury to the building were considered as one wrong," and met The Haxby case by saying that there was no violence in the present case. It accepted Mr. Benedict's statement ${ }^{\mathbf{1 7 0}}$ based on The City of Lincoln that "loss of cargo by the giving way of a wharf and the casting of the cargo into the water is cognizable in admiralty". Nevertheless, the present writer is inclined to disbelieve that the California case has met the difficulty which Judge McPherson set forth in The Haxby when he said, ${ }^{171}$ "Let us suppose . . . that the property had been upon another vessel, and had been hurled into the water from its deck. In that event the libellant would scarcely have followed the property to the bottom of the river in order to oust the admiralty jurisdiction by averring that the damage was suffered upon the land there submerged. Why, then, should the libellant be permitted now to deny that the injury was done upon the pier, and to follow the blocks and tools into the water, in order to establish the jurisdiction? In both cases I think it would be more reasonable to hold that, as the sequence of events was inevitable, the whole transaction should be regarded as taking place where the violence was inflicted." Notwithstanding the fact that in the California case there was no violence and the collapse was simply due to the weight, it was obviously on the wharf that the wharf owner failed to give the sardines the support for the lack of which the force of gravity drew them into the water. The case does not seem to have reached a proper conclusion.

The principle of the California case has scarcely been approved in the Supreme Court. In Evanswille \& Bowling Green Packet Co. v. Chero Cola Bottling Co.," ${ }^{172}$ the Court reports simply that "a wharfboat . . . sank, causing a damage to . . . merchandise thereon". Nothing is said concerning the character of the tort, as the opinion deals wholly with limitation of liability, which it denied on the ground that the wharfboat was not a "vessel" within the provisions of the Liability Act. Since, if the boat was a vessel, the Court could not now limit against a non-maritime ${ }^{173}$ tort, the case is not illuminating on the present inquiry. But in the personal injury cases, the discussion of which follows, the Supreme Court finds the point of injury for a man drowned by being hurled from the dock into the water not on the water, but on the dock. In Smith \& Son, Inc. v. Taylor, ${ }^{174}$ where such were the facts, the Court said, "The substance and consummation of the occurrence which gave rise to the cause of action took place on the land." Its

I70. BENEDICT, AdMIRAITY (5th ed. I925) 199.

I7I. 95 Fed. I70, I7I (E. D. Pa. I899).

I72. 27 I U. S. I9 (I926), cited note I02, supra.

I73. Richardson v. Harmon, 222 U. S. 96 (I9II).

I74. 276 U. S. I79, I82 (I928). 
holding rather definitely upsets the view that the accident restoring the sardines to the sea is to be classed as a maritime tort, and it may safely be said that injuries to land structures by reason of which articles are pitched into the water and there damaged are not, as to any part of the injury, within the admiralty jurisdiction.

\section{(b) In Personal Injury Cases}

If it can be said that the place of personal injury is on a ship, there is maritime jurisdiction. Presumably if it is on one of the "aids to navigation" of the Blackheath doctrine, ${ }^{175}$ there is maritime jurisdiction, and the keepers of harbor lighthouses or their caretakers, if injured "aboard", have a maritime cause of action. The case on this has not yet arrived. Certainly if it is on the dock or wharf or other structure equivalent to "land" there is not such jurisdiction. Putting aside the question, previously discussed, of the nature of the business which brings the person on board, this, in brief, is the working theory. A ship aground is not a land structure-at least not during efforts to work her off; and when a man on board her is injured by the snapping of a hawser which tugs are "surging" on, the injury is maritime.178 When all the elements of the transaction-the actor, his act, and their effect upon the victim of the injury-occur wholly on ship or wholly on land the jurisdiction is clear. Even though the victim of the injury may be, as he usually is, engaged in some general work concerning the vessel, the Supreme Court has said in State Industrial Comm. v. Nordenholt Corp. ${ }^{177}$ : "When an employee, working on board a vessel in navigable waters, sustains personal injuries there . . . the applicable legal principles are very different from those which would control if he had been injured on land while unloading the vessel. In the former situation the liability of employer must be determined under the maritime law ; in the latter, no general maritime rule prescribes the liability, and the local law has always been applied." The New York Court of Appeals had in these cases taken the view that the state compensation act was contractual in character ${ }^{178}$ and had then concluded that the maritime nature of the man's contract had excluded the state law. The theory had the merit of governing the whole working area of the man's job by a single scheme of legal adjustment for injury sustained while at work. The Supreme Court rejected it. ${ }^{179}$

175. The Blackheath, 195 U. S. 36I (1904).

I76. Payne v. Jacksonville Forwarding Co., 290 Fed. 936 (C. C. A. 5th, I933). The point was assumed in the suit for maritime tort.

I77. 259 U. S. 263,272 (I922).

I78. It affirmed 195 App. Div. 913 (3d Dep't I92I) on memo in 232 N. Y. 507, I34 N. E. 549 (I92I). In Doey v. Howland Co., 224 N. Y. 30, I20 N. E. 53 (IgI8) however, the court set forth its theory. The topic is discussed in the author's article, loc. cit. sispra note 3 . On the topic of the development of the idea that a workmen's compensation act is a job coverage extending to injuries outside the territorial limits of the enacting sovereign, see R. H. Dwan, Workmen's Compensation and the Conflict of Laws (Ig27) II MINN. L. REV. 329.

I79. State Industrial Comm. v. Nordenholt Corp., 259 U. S. 263 (I922). 
The practical result of the Supreme Court's doctrine, on the other hand, is that there is no unity in the law governing a man's job when his work calls for moving back and forth between the ship and the shore. Loading or unloading a ship moored alongside a dock is work in which a man's job is in its nature continuous and indivisible. Yet it is divided for purposes of the applicable law physically in half. The case which accepts this situation most baldly is the famous Southern Pac. Co. v. Jensen, ${ }^{180}$ where Jensen was unloading freight from a steamer to a pier and happened to break his neck while at the ship end of his run. His injury was so strictly maritime that the state compensation act, the Supreme Court said, could not apply to it. On the other hand, had he broken his neck while at the dock end of his run the shore law would govern. In a later case a man whose work was part of the general job of unloading a vessel, but who was engaged at the moment in tiering up sacks of cement as they were hoisted to him on the dock, slipped and fell from the pile of bags upon the dock. It was the state law which governed, and its compensation act covered the injury. "Insana was injured upon the dock, an extension of the land, Cleveland Terminal and $V . R . R$. Co. v. Cleveland S. S. Co., ${ }^{181}$ and certainly prior to the workmen's compensation act the employers' liability would have rested upon the common law and the state statute", said the Court in Industrial Comm. v. Nordenholt Corp. ${ }^{182}$ in so holding.

In The Whisper, ${ }^{183}$ where a ship master first clubbed a man with an iron pipe while both were on board, and "some considerable time" later clubbed him again on shore, the court held it was error to allow him to recover in admiralty for the dual clubbing because the two were "independent transactions". ${ }^{184}$ A recovery for the clubbing on board would be proper, and the circuit court threw back upon the trial court the task of determining its exact amount. The time break made this decision easier than it is in the cases where there is a continuous transaction. In such a case the problem of locating the point of injury becomes metaphysical for any one who accepts the cases, and it presents a conflict of decisions for one who does not. It will be remembered that the Plymouth rule has it that "at least the substance and consummation" of the injury must take place on the waters. It is not necessary that the whole, from inception to conclusion, should there occur. This is merely another phase of the problem of where to localize the injury which

I80. 244 U. S. 205 (I9I7).

I8I. 208 U. S. 316 (1908).

182. 259 U. S. 263 (I922).

183. 268 Fed. 464 (C. C. A. 6 th, 1920).

184. The interval of time simplified the court's problem, for it said at p. 467: "The transaction on the shore was a wholly separate and independent transaction from the assault upon the boat. Whatever may have occurred upon the shore was clearly not a maritime tort, and not within the jurisdiction of a court of admiralty." In Steele v. Thacher, I Ware 9I (D. C. Me. I825) a captain shipped the plaintiff's "son, a minor, at Portland," and transported him to parts beyond the seas. The father sued in admiralty for loss of services and won. Judge Ware considered that "the substance" of the tort was committed on the high seas. 
was dealt with in the cases involving property damage on wharves, etc. If a man on board a ship is injured there by a bit of lumber put on a chute at its wharf without the customary shout of warning from those working there he may sue in admiralty. Herman v. Port Blakely Mill Co. ${ }^{185}$ held that he was injured on the ship and it was not necessary that the negligence should also be on the ship. On the other hand, if a man at work on the ship is struck there by a swinging cargo hoist and knocked off the ship to the wharf, there is admiralty jurisdiction. The tort is maritime, according to Minnie v. Port Huron Terminal Co. ${ }^{186}$ Chief Justice Hughes said, "the injury was due to the blow . . . received on navigable water. . . ." It was, he said, the converse of $T$. Smith \& Son, Inc. v. Taylor, ${ }^{187}$ where the sling struck the man while he was on the wharf and threw him into the water. Though the sling was operated from the ship's winch, the court held that the injury had occurred on land.

Some of the cases are not so clear, however, as to just where to locate the injury, particularly in what may be called the ladder cases. In The H. S. Pickands ${ }^{188}$ Judge Brown ${ }^{189}$ dealt with the following facts: the Pickands was lying at a wharf; leading to her bulwarks was a ladder which had been secured at its wharf end by a cleat; a moment prior to the libellant's descent from the ship the ship's master had moved it from the cleat, and when the libellant started down the ladder he fell and struck the wharf. The court denied jurisdiction. Its theory, however, is obscure. The master, standing on the ship, moved the ladder, but the court says that the slip of the ladder which caused the injury occurred on the land-the place where the damage was done. The court admitted that prior cases had allowed recovery. ${ }^{190}$ Yet, in another ladder case, The Strabo, ${ }^{101}$ an exception was taken against the admiralty jurisdiction, and despite the Pickands case the jurisdiction was sustained. Here, too, a man was leaving a ship by a ladder which slipped and threw him to the "ground". However, in this case the ladder was improperly fastened to the ship's rail. The court stated that it had been assumed that the ladder was part of the ship and if so the man received the effect of the wrongful act on the ship when he mounted the ladder. It also played with the idea that he was injured by nervous shock before he struck the dock, a

I85. 69 Fed. 646 (N. D. Cal. I895). Judge Morrow points out an "inadvertent remark" in the opinion of The Mary Stewart, Io Fed. I37 (E. D. Va. I88I) that both the wrong and the injury must occur on the water. In the Stewart case the man was injured while standing on a wharf by a bale of cotton which fell from the ship's tackle when a rope on the ship broke. Jurisdiction was denied, the court saying the "injury was on land".

I86. 295 U. S. 647 (I935).

I87. 276 U. S. 179 (I928).

I88. 42 Fed. 239 (E. D. Mich. 1890 ).

I89. Later Mr. Justice Brown, and as an admiralty lawyer the subject of Judge Hough's appreciation in the latter's article, loc cit. supra note 9 .

I90. E. g., The Daylesford, 30 Fed. 633 (S. D. Ala. 1887); The Carolina, 30 Fed. 199 (E. D. N. Y. I886) but the court went on to say that in neither case had the point of jurisdiction been noticed.

I91. go Fed. Iro (E. D. N. Y. I898). 
point which the affirming court expanded, ${ }^{192}$ so that by this rationalization both the negligence and the injury took place on ship. The Pickands case went on the ground that the negligence as well as the fall were on the wharf, notwithstanding that the master was on the ship when he shifted the ladder away from the cleat.

As a note writer says, "It is difficult to reconcile these decisions on principle." ${ }^{193}$ Nevertheless, the two cases are cited as apparently consistent with each other by Mr. Benedict ${ }^{194}$ notwithstanding the specious arguments of both opinions. On the other hand, jurisdiction was denied in the case of a man who, expecting to find a gangplank from wharf to ship, walked overboard before he discovered that those on the ship had removed the plank formerly there. In this case, The Albion, ${ }^{195}$ the court simply cited The $H$. S. Pickands. But in The Atna ${ }^{196}$ a court held there was jurisdiction in a case where a longshoreman who had been working on the ship started ashore by a ladder which the ship owned and which broke and dropped with him into the water, where either the ladder or a fender log injured him. The test used was whether, if the victim left the ship, he was free of it when injured, or vice versa if he left the shore; the court considering his "status" unchanged until he reached his objective point. Since he had left the ship and not reached the shore, this line of reasoning made his injury maritime in character.

Recently, in Kenward v. The Admiral Peoples, ${ }^{197}$ the Supreme Court granted certiorari in view of the asserted conflict (of a lower court's ruling) with other decisions of the federal courts, citing the cases above. A passenger on a steamer was disembarking and was injured by a fall from a gangplank which led from the vessel to the dock. At the shore end of the plank the thickness of the plank itself made a six-inch step, and since she reached this step without being aware of it, she fell to the dock. Said Chief Justice Hughes:

"This is one of the border cases involving the close distinctions which from time to time are necessary in applying the principles governing the admiralty jurisdiction. That jurisdiction in cases of tort depends upon the locality of the injury. It does not extend to injuries caused by a vessel to persons or property on the land. Where the cause of action arises upon the land, the state law is applicable.

"The basic fact in the instant case is that the gangplank was a part of the [vessel's equipment] which was placed in position to enable its passengers to reach the shore. It was no less a part of the vessel because

I92. In The Strabo, 98 Fed. 998 (C. C. A. 2d, I900), the ruling denying the exception to jurisdiction was sustained. It said "The injury commenced when, by the slipping of the ladder, the libellant was thrown in the air." Id. at I000.

I93. Note (I926) 24 MICH. L. Rev. 405, 406.

194. BENEDICT, op. cit. stpra note I70.

195. I23 Fed. I89 (D. Wash. 1903).

I96. 297 Fed. 673 (W. D. Wash. I924).

197. 295 U. S. 649 (1935); Note (1936) to Tulane L. Rev. 300. 
in its extension to the dock it projected over the land. Thus, while libellant was on the gangplank, she had not yet left the vessel. This was still true as she proceeded to the shore end of the plank. If while on that part of the vessel she had been hit by a swinging crane and had been precipitated upon the dock, the admiralty would have had jurisdiction of her claim. If instead of being struck in this way, the negligent handling of the vessel, as by a sudden movement, had caused her to fall from the gangplank, the cause of action would still have arisen on the vessel. We perceive no basis for a sound distinction because her fall was due to negligence in the construction or placing of the gangplank. By reason of that neglect, as the libel alleges, she fell from the plank and was violently thrown forward upon the dock. Neither the short distance that she fell nor the fact that she fell on the dock and not in the water, alters the nature of the cause of action which arose from the breach of duty owing to her while she was still on the ship and using its facility for disembarking. courts." 198

"This view is supported by the weight of authority in the federal

Where the man is on a dock, etc., at the time when he is struck by something thrown or swung from the ship the courts have had no such trouble with the facts as in the ladder cases. In the Supreme Court, a late case of this sort is T. Smith and Sons v. Taylor. ${ }^{199}$ Taylor, a stevedore, who stood on a staging on the dock, was struck by a sling negligently operated by the vessel's winch during unloading. He was knocked into the water where he was later found dead. There is nothing in the opinion about his injury by or in the water except the statement that the defendant party "argues that as no claim is made for injuries sustained while the deceased was on land and as the suit was solely for death that occurred in the river, the case is exclusively within the admiralty jurisdiction". To which the Court replied: "But this is a partial view that cannot be sustained. The blow by the sling was what gave rise to the cause of action. It was given and took effect while deceased was upon the land. . . . The substance and consummation of the occurrence which gave rise to the cause of action was on land. The Plymouth. This case cannot be distinguished from Johnson v. Chicago Elevator Co." 200 This was no new doctrine. Another recent illustration of it is The Bee. ${ }^{201}$ There a man on a railroad car on a shore track was struck and injured by a sling load of lumber transferred from car to ship by a hoist located on the ship and negligently operated there by the mate. Application of a state law giving a lien on the ship was sustained. In Swayne \& Hoyt $v$. Barsch $^{202}$ a man working on a dock was injured there by too quick with-

I98. 295 U. S. at 65 I.

I99. 276 U. S. 179 (I928). The precise question was whether or not the state compensation act applied. The state courts held it did and the Supreme Court affirmed their holding. 200. Id. at 182 . The cases mentioned are discussed on pp. 719, 720, supra.

201. 216 Fed. 709 (D. Ore. I9I4).

202. 226 Fed. 58 I (C. C. A. 9th, 1915). 
drawal of tackle operated from the ship. A state act was applied. In Keator v. Rock Plaster $M f g$. $\mathrm{Co}^{203}$ a load of rock from a ship spilled upon a man standing on the dock. The state law was applied; the man's maritime contract did not operate to give admiralty jurisdiction. ${ }^{204}$ Smalls v. Atlantic Coast Shipping $\mathrm{Co}^{205}$ concerned injury to a longshoreman, who was at the time on land, due to a defective winch on the vessel. The case was held not to be within maritime jurisdiction.

Another line of cases involving injury to men working on ships when the ships are under repair has led to some fine distinctions. So long as the ship is fully afloat no question arises as to the maritime character of the injury, but ships are often worked upon while they are out of water. And they may be out of water on a purely land structure or out of water on a structure which itself is afloat. They may also be on a marine railway which stretches from land into water, and a vessel on it may itself be wholly or only partially out of water. Actually, in so far as the cases go these distinctions have been largely ignored, and the causes of action have been regarded as maritime even when the vessel at the time of the injury is not water-borne either directly or indirectly. ${ }^{206}$

The further question of structures which are on land but are used for maritime purposes is sharply raised concerning dry docks, particularly in instances where men have sustained injuries while repairing a vessel in a dry dock. In the Anglo-Patagonian ${ }^{207}$ maritime jurisdiction was upheld notwithstanding that the workman was injured, not on the vessel, but upon a scaffold erected on her outside. The contention that the accident happened on land and was not cognizable, the court said, rested on "no sustainable basis". Yet the dock in the case was a hole in the ground into which. the ship floated. The result, however, was tacitly accepted by the Supreme Court in Gonsalves v. Morse Dry Dock \& Repair Co., ${ }^{208}$ wherein Justice McReynolds remarked: "In the Robert W. Parsons 209 . . . this Court held that repairs to a vessel while in an ordinary dry dock were not made on land." 210 In the Gonsalves case, the repairs were made upon the ship while in a floating dry dock. "Clearly, the accident did not occur upon land. The doctrine followed in Cope v. Vallette Dry Dock Co., ${ }^{211}$. . . that

203. 256 Fed. 574 (S. D. N. Y. I919).

204. See however, supra p. 748, for the view taken by the New York Court of Appeals. 205. 26I Fed. 928 (E. D. Va. 1919).

206. See Robinson, stipra note $I$, at $8 \mathrm{r}$.

207. 235 Fed. 92 (C. C. A. 4th, I916). Contra: The Warfield, I2o Fed. 847 (E. D.

N. Y. I903).

208. 266 U. S. I7I, I72 (I924).

209. I9I U. S. 17 (I903).

210. 235 Fed. at 95. The Anglo-Patagonian opinion based itself on the Robert Parsons case, adding that under that decision if the dry dock company had a maritime "contract we perceive no reason why its employees engaged in making the repairs may not sue in admiralty". Ibid. See Stumberg, supra note 9, at 3II, for a discussion of the case.

2II. II9 U. S. 625, 627 (I886). 
'no structure that is not a ship or vessel is a subject of salvage,' has no application. That admiralty jurisdiction in tort matters depends upon locality is settled". ${ }^{213}$ The dismissal of the libel was reversed. Whatever limitation may be intended by the words "ordinary dry dock" as used in the quotation from the Robert $W$. Parsons, was specifically disclaimed by the Supreme Court in I9I9 in North Pacific S. S. Co. v. Hall Bros. Marine $R y . S$. B. Co. ${ }^{214}$ when, after referring to The Parsons it said that the admiralty jurisdiction extended to repair contracts independently of whether they were made upon a vessel "afloat, while in dry dock, or while hauled up by ways upon land."

When the Federal Harbor Workers' and Longshoremen's Act was enacted in 1927, the "coverage" section specifically included injury upon "navigable waters of the United States (including dry dock)". How far this phrasing has affected the problem is discussed at a later point. In Taylor v. Lawson, ${ }^{215}$ the act was declared by a district court to extend to injury of a man working on a new ship put into dry dock after launching, but the district court's view did not prevail. In reversing, the circuit court of appeals said: "Such work is not maritime in the accepted meaning of that term", and the cases "make it clear that a state has power to provide compensation for injuries suffered by a workman employed in the construction of a vessel afloat upon navigable waters." 216 In Norton v. Vesta Coal $\mathrm{Co}^{217}$ a man injured while at work on a vessel which had been hauled out of water completely by use of a marine railway was awarded compensation under the new act. The majority of the court said Congress meant a "dry dock" in the common acceptance of the term and "we take Congress at its word." The reasoned dissenting opinion described the various methods of getting at the ship's hull and stressed the language of the Act, not on "dry' dock" merely but on "any" dry dock as showing an intent to include all the several instrumentalities for accomplishing the maritime work. ${ }^{218}$

212. The impact of the Supreme Court's more recent decisions upon the minds of the "inferior" federal courts is seen in United States v. Bruce Dry Dock Co., 65 F. (2d) 938 (C. C. A. 5th, I933) which sustained a tort action in admiralty in behalf of a floating dry dock. The court said "it has no connection with commerce on land", and cited the Raithmoor, Gonsalves v. Morse Dry Dock Co., Doullut \& W. Co. v. U. S.; adding: "Cope v. Vallete D. $\mathrm{D}$. Co. is not to the contrary: it merely holds that a floating dry dock is not a subject of salvage service, because not a ship or vessel." II. at 942 .

213. 266 U. S. I7I, 172 (1924).

214. 249 U. S. II9 (I9I9), 32 HARv. L. REv. 853.

215. 60 F. (2d) I65 (E. D. S. C. I932), (I933) 46 HARv. L. Rev. 7II, rev'd sub nom, United States Casualty Co. v. Taylor, 64 F. (2d) 521 (C. C. A. 4th, 1933), cert. denied, 290 U. S. 639 (I933).

216. 64 F. (2d) at 524.

217. 63 F. (2d) 165 (C. C. A. 3d, I933), cert. granted, 290 U. S. 613 (I933). In 291 U. S. 64I (I934), the Court said: "Per curiam: As it appears that the Government has now adopted the conclusion that the decision below is correct . . . the writ of certiorari herein is dismissed."

2I8. He concluded: "Although the question whether, under the statute, the term 'any dry dock' includes a marine railway is debatable, as shown by opposite decisions in Colonna's 


\section{Division of Damages}

It must be remembered that for the present purpose only the admiralty jurisdiction in tort is being considered, that is, whether the maritime law may be properly invoked in the fact situation presented. Actually, both procedural and substantive law are involved if jurisdiction be found. So far as the general basis of liability is concerned, it has traditionally been the same in the corpus juris maris, as the latter has been selected and applied in our courts, as it is at common law. In both it has been predicated on fault. Aside from a partial job insurance for seamen, recovery for maritime injury, whether to property or to person, was in all cases based on negligence. But in admiralty law the fault may be attributed not merely to some person for acts per se or per alium but also to the ship itself, and it may be attributed so that the injured thing or person may have a very special security for damages under maritime liens beyond anything which the common law may be able to afford. Furthermore, the plaintiff who is able to invoke the maritime jurisdiction if contributorily negligent has immunity from the common-law effect of contributory negligence, as already adverted to in dealing with the collision of vessels with land structures. The confusion there outlined with respect to viewing contributory negligence as a matter of "substance" or of "procedure" has made the right to invoke the maritime rather than the common-law jurisdiction particularly valuable in respect to the matter of the damages.

In the property injury cases the admiralty courts follow the simple formula of adding the respective amounts of damage together and assessing the negligent parties equally. ${ }^{219}$ But although in dealing with persons the admiralty courts now use the divided damage principle, the mathematics of division is not so simply stated, and the question whether to divide damages or dismiss was not decided until I89o. In The Max Morris ${ }^{220}$ one Curry was injured at work on board a ship as a coal loader. He libelled in rem and on the ship owner's claiming that the man's contributory negligence should defeat him the case was certified to the Supreme Court on that point. The Supreme Court itself says it was the first time it had been called upon to answer the question. On the main point it responded that "Contributory negligence, in a case like the present, should not wholly bar recovery. . . . We think this rule is applicable to all like cases of marine tort founded upon

Shipyard v. Lowe (D. C.) 22 F. (2d) 843 , and Continental Casualty Co. v. Lawson (D. C.) 2 F. Supp. (2d) 459 , and by a permissible inference from the decision in North Pacific S. S. Co. v. Hall Bros. Marine Ry. \& Shipbuilding Co., 249 U. S. II9, I28, 39 Sup. Ct. 22I, 63 L. Ed. 5IO, I am of opinion that the judgment below, on a finding that a marine railway is not included, should be reversed." 63 F. (2d) at I68.

219. Sprague, Divided Damages (I928) 6 N. Y. U. L. Q. Rev. I5.

220. The Max Morris v. Curry, I37 U. S. I (1890). 
negligence and prosecuted in admiralty, as in harmony with the rule for the division of damages in cases of collision." 221

The method of division, however, the Court did not deal with. "Whether, in a case like this, the decree should be for exactly one-half of the damages sustained, or might, in the discretion of the court, be for a greater or less proportion of such damages, is a question not presented for our determination upon this record, and we express no opinion upon it." 222 Thus left to their own devices the trial courts have not actually split the damages half and half. In Carter $v$. Brown ${ }^{223}$ the court quoted the language of The Max Morris and said that even if there was contributory negligence the sum fixed by the district judge in the injured man's behalf gave no cause for complaint in view of the serious character of the injuries. In Storgard $v$. France \& Canada S. S. Corp.,"24 the contributory negligence "is an element which may be considered in determining what the amount of indemnity should be". ${ }^{225}$ In The Henry S. Grove ${ }^{226}$ the court put it that "Even if he had been [contributorily negligent] under the [seaman's act] . . . recovery would not be defeated by contributory negligence, although the doctrine of comparative negligence, with resulting diminution in the amount of recovery, would apply as formerly." 227 The italicized phrase indicates how far the idea of equal division had been abandoned by the particular trial judge. So far as injuries to seamen are concerned, the Act of $1920{ }^{228}$ imposes the comparative negligence rule, as does the Federal Death Act of $1920,{ }^{228}$ while the Federal Longshoreman and Harbor Workers' Statute is a compensation act and deprives the injured man's contributory negligence of significance altogether.

In view of these special statutes, however, the reader is warned that the foregoing exposition of the general principles of tort jurisdiction in admiralty may no longer be applicable to the case of the particular individual injured nor indeed to the death action of a person to whose mere injury they might otherwise apply. The classification of the man or of his misfortune under one or another of these acts may affect the general result of the very case. He is further warned that the question of how far the Limitation of Liability Act may cut down recovery of damages is not a part of this paper, which is already too long.

22I. Id. at I4.

222. Id. at I5.

223. 212 Fed. 393 (C. C. A. 5th, 1914).

224. 263 Fed. 545 (C. C. A. 2d, I920).

225. 263 Fed. at 547.

226. 22 F. (2d) 444 (D. Md. I927).

227. Id. at 447. (Italics added.)

228. 4I STAT. I007 (I920), 46 U. S. C. A. \$ 688 (I928).

229. 4 I StAT. 537 (I920), 46 U. S. C. A. $\$ \$ 76 \mathrm{I}-762$ (I928). 